\title{
Euron RISTIRIIDAT Ja SAKSAn talousmalli
}

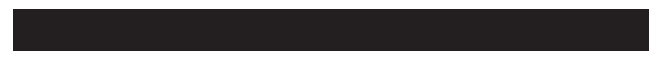

Lissabonin sopimuksessa vuonna 2000 julistettiin suureellisesti, että Euroopan unionista on tarkoitus tehdä maailman menestynein, innovaatioille perustuva tietopohjainen talous. Sopimuksen solmimisen jälkeen kuluneiden 15 vuoden aikana euroalueen talouskasvu on kuitenkin jatkuvasti ollut selkeästi hitaampaa kuin Yhdysvalloissa, Aasian maissa tai euroalueen ulkopuolisessa Euroopassa (esim. Sveitsissä tai Ruotsissa). Nimenomaan korkean arvonlisäyksen alat - tai "innovaatiot" mitä ikinä niillä sitten tarkoitetaankaan - ovat keskittyneet huomattavasti voimakkaammin Kalifornia-Kiina-akselille kuin Eurooppaan. Jo ennen talouskriisiä eli vuosina 2001-2007 euroalueen bruttokansantuote kasvoi keskimäärin vain 1,9 prosenttia vuodessa, kun $\mathrm{Yh}$ dysvalloissa talouskasvu oli keskimäärin 2,4 prosenttia, Isossa-Britanniassa 2,6 prosenttia tai Ruotsissa 3,0 prosenttia vuodessa (Sapir 2012: 59). Erityisesti Euroopan suurin talous Saksa on keskittynyt ennen kaikkea autojen ja tuotantovälineiden vientiin, ja sen keskeisimpänä kilpailuvalttina eivät ole olleet innovaatiot vaan suhteellisen matalat palkat ja valuuttakurssi.

Mistä Euroopan epäonnistuminen tietopohjaisen talouden rakentamisessa sitten johtuu?

Vuodesta 2007 jatkuneen kriisin aikana on usein korostettu, että Maastrichtin sopimuksessa määritetyt ja vuonna 2012 allekirjoitetussa niin sanotussa Fiscal Compactissa vahvistetut taloussäännöt, ennen kaikkea euromaiden julkisen talouden alijäämälle asetetut rajoitukset sekä EKP:n asema julkista kulutusta hillitsemään eikä tukemaan pyrkivänä ins- tituutiona ovat heikentäneet alueen talouskasvua ja kasvattaneet työttömyyttä (luultavasti täsmällisimmin leikkausten ja talouskasvun yhteyttä ovat tarkastelleet de Grauwe \& Yi 2013). Kuten todettu, ne ovat heikentäneet kasvua jo ennen kriisiä, mutta niitä ei ole syytä tarkastella irrallisina raha- tai talouspoliittisina mekanismeina vaan yhteydessä tiettyyn työn ja tuotannon järjestämisen tapaan, johon ne liittyvät.

Tarkoitukseni on tutkia, millä tavoin euro rahajärjestelmänä on jäsentänyt uudelleen pääomasuhdetta työn ja pääoman välisenä valtasuhteena sekä muita yhteiskunnallisia valtasuhteita. Koska pääoma on suhde abstraktin rahavirran ja sen arvoa lisäämään alistetun työvoiman välillä, kumman tahansa suhteen osapuolen hävittäminen tai ratkaiseva muutos uhkaa aina tehdä itse suhteesta epävakaan. Nähdäkseni nykyiselle finanssivetoiselle kapitalismille ominainen makrotaloudellinen epävakaus onkin viime kädessä peräisin siitä, että niin sanotun fordistisen vakaan yhteiskunnallisen kompromissin hajottaminen ja perinteisen ammattiyhdistysliikkeen tai institutionaalisen työväenliikkeen kriisi ovat tehneet koko globaalista kapitalismista hyvin epävakaan. Kun tuottavuushyötyjä ei ole fordismin tapaan jaettu palkkatulon kautta, kysynnän puutteesta on tullut vakava ongelma koko globaalille taloudelle, ja samalla pankkijärjestelmän luoma raha ei näytä muuttuvan tuottaviksi investoinneiksi vaan jää pelkästään finanssitaloudelliseen kiertoon (eikä juuri siksi muutu myöskään efektiiviseksi kysynnäksi).

Erityisesti vuodesta 2011 lähtien koko euroalueen taloutta on pyritty rakentamaan 
lähes puhtaasti vientiteollisuuden perustalle, ja siksi se heijastaa erityisen hyvin näitä globaalin kapitalismin ristiriitoja. Tarkoitukseni on osoittaa, että Saksan talousmalli - jonka pohjalle euro on rakennettu - on aina 1950-luvulta lähtien nojannut vientiin, koska Saksassa fordistista luokkakompromissia ja siihen liittyvää työvoiman kokoonpanoa ei koskaan ollut olemassa. Saksassa on siis jo pian 70 vuoden ajan "kokeiltu" tietynlaista pääomasuhteen järjestämisen tapaa, jossa pääomasuhde on tavallaan hajautettu globaalille tasolle: työvoiman poliittiset instituutiot on hajotettu "kotimaassa", jotta palkkakustannuksia voitaisiin alentaa mahdollisimman paljon, ja kysynnän luominen on "ulkoistettu" muualle. 1950-luvulta 1970-luvulle Saksa oli (Japanin ohella) poikkeus globaalissa taloudessa, mutta nyt kun tätä talousmallia yritetään soveltaa lähes koko globaalin talouden mittakaavassa, se näyttää ajaneen koko kapitalismin jo miltei vuosikymmenen jatkuneeseen kriisiin.

Lähden euroalueen talouskehityksen analyysissa liikkeelle näkemyksestä, että itse rahalla ja rahajärjestelmällä on ratkaiseva merkitys myös tuotannon ja työn järjestämisen tapojen kannalta, eikä raha ole pelkästään neutraali taloudellisten "fundamenttien" ilmaisu vaan perustava yhteiskunnallinen suhde, joka asettaa tuottajat suhteisiin keskenään (ks. Aglietta \& Cartelier 1998; Graziani 2003). Raha on siis valtaa tai komentoa, ennen kaikkea valtaa tai kykyä ostaa tulevaa työtä, työvoimaa ja siten ohjata yhteiskunnallisen tuotannon päämääriä. Samalla tämä kuitenkin tarkoittaa, ettei rahaa ja rahajärjestelmää voida tarkastella pelkästään abstraktien kirjanpidollisten suureiden näkökulmasta eikä irrottaa tuotantosuhteista tai työn järjestämisen tavoista. Raha tai rahajärjestelmä ja työ sekä tuotanto ovat erottamattomassa suhteessa toisiinsa. Koska raha on valtasubde, sitä voidaan ymmärtää ainoastaan tarkastelemalla niitä työn ja tuotannon muotoja, jotka ovat suhteen osapuolina.

\section{EUROALUEEN RISTIRIIDAT}

Kun yhteisvaluuttajärjestelmää luotiin, sen odotettiin lähentävän alueen talouksia toisiinsa, mutta tosiasiassa se on vain lisännyt eri jäsenmaiden välisiä taloudellisia eroja. Tämä on ollut tiedossa jo vähintään euroalueen talouskriisin pahenemisesta alkaen, mutta näkemystä vahvisti entisestään Euroopan keskuspankin kesällä 2015 julkaisema raportti (EKP 2015). Sen mukaan euroalueen sisällä erot bruttokansantuotteessa henkeä kohti ovat yhteisvaluu$\tan$ olemassaolon aikana kasvaneet.

Yleisesti ottaen yhteisvaluuttajärjestelmän rakenne on kärjistänyt alueen sisäisiä eroja kahdella tavalla:

1) Kuten esimerkiksi niin euroa kannattava Michel Aglietta kuin sitä vastustava Jacques Sapir ovat todenneet, itse valuutan arvo suhteessa muihin valuuttoihin, ennen kaikkea dollariin, jeniin ja renmimbiin, on ollut matalampi kuin Saksan markan arvo itsenäisenä valuuttana olisi muuten todennäköisesti ollut ja toisaalta korkeampi kuin pesetan tai drakhman arvo itsenäisenä valuuttana olisi ollut (Aglietta 2012, Sapir 2012). Samalla korkotasojen yhteneminen alueen sisällä on johtanut siihen, että korkotaso Etelä-Euroopan maissa on madaltunut huomattavasti. Korkotaso on siis ikään kuin ollut liian korkea Saksalle ja liian matala Etelä-Euroopan maille. Seurauksena erityisesti Kreikan, Espanjan, Italian ja Portugalin sekä myös esimerkiksi Ranskan vientiteollisuuden kilpailukyky suhteessa Saksaan on heikentynyt, kun valuutan arvon aleneminen suhteessa D-markkaan ei enää ole ollut mahdollista. Euron olemassaolon aikana eri jäsenmaiden inflaatioasteiden erot taas ovat ainoastaan kasvaneet aiempaan verrattuna. Vuosina 2001-2007 inflaatio oli Saksassa keskimäärin 1,1 prosenttia ja Suomessa 1,2 prosenttia, mutta Espanjassa 4,1 prosenttia ja Irlannissa sekä Kreikassa 3,2 prosenttia (Sapir 2011: 51-52). EU:n komissio arvioi vuonna 2009, että jos kansalliset valuutat olisivat vielä 
olleet käytössä, Espanjan, Portugalin ja Kreikan valuuttojen arvon olisi pitänyt laskea noin 15 prosentilla 2000-luvun aikana ja D-markan nousta saman verran. Siksi pelkästään valuutta oli aiheuttanut noin 30 prosentin reaalisen kilpailukykyeron Saksan ja Etelä-Euroopan maiden välille. Euron ansiosta Saksa on saanut vientituotteilleen rajoittamattoman pääsyn naapurimaiden markkinoille ja samalla estänyt niitä parantamasta kilpailukykyään devalvoimalla valuuttaansa.

2) EKP:n omassa raportissa (2015) todetaan, että kilpailukykyerojen kasvun syvempänä rakenteellisena syynä on ollut se, että investoinnit niin sanottuun inhimilliseen pääomaan, ennen kaikkea koulutukseen ovat jääneet liian alhaisiksi Etelä-Euroopan maissa. EKP:n raportti ei tietenkään sano suoraan, mikä koulutusinvestointien vähäisyyden syynä on, mutta epäilemättä keskeinen syy ovat nimenomaan Maastrichtin sopimuksen julkisia menoja rajoittamaan pyrkineet parametrit (joiden mukaan julkisen velan määrä suhtessa BKT:hen saa olla korkeintaan $60 \%$ ja julkisen talouden alijäämä korkeintaan 3 \% BKT:sta). Toisin sanoen kilpailukykyerojen tasaaminen euromaiden välillä olisi vaatinut merkittäviä lisäinvestointeja koulutukseen Italiassa, Espanjassa, Portugalissa, Kreikassa ja niin edelleen, mutta talouskurisäännöt ovat estäneet nämä investoinnit, minkä seurauksena erot kilpailukyvyssä ovat euron luomisen jälkeen ainoastaan pahentuneet.

Michel Aglietta ja Thomas Brand korostavat (2015: 84-87)), että erityisesti nykyisessä tieto- ja palveluvetoisessa taloudessa kasvu keskittyy maantieteellisesti. Jo ennen yhteisvaluutan syntyä korkean arvonlisäyksen tuotanto ja ylipäätään taloudellinen kasvu oli Euroopassa keskittynyt ennen kaikkea läntiseen Saksaan, Pohjois-Ranskaan, Benelux-maihin, Kataloniaan ja Pohjois-Italiaan. Mikäli tämä maantieteellinen keskittymistendenssi olisi haluttu kääntää, olisi vaadittu aktiivisia aluepoliittisia toimenpiteitä. Toki Euroopan unioni on laajentuessaan luonutkin erilaisia rahastoja ja toimenpideohjelmia, joiden avulla on rakennettu esimerkiksi uusia rautateitä ja tieverkostoja Etelä-Italiaan, Etelä-Espanjaan ja muille köyhemmille alueille, mutta toimet ovat jääneet aivan liian vähäisiksi, jotta ne olisivat voineet kääntää keskittymiskehityksen ympäri. Itse yhteisvaluutan institutionaalinen rakenne, joka on pakottanut vähentämään julkisia investointeja, on lisäksi kärjistänyt keskittymistä entisestään.

Marcel Fratzscher osoittaa kirjassaan Die Deutschland-Illusion, että myös Saksan 2000-luvun alun "talousihme" perustui ennen kaikkea matalaan palkkatasoon (sekä toissijaisten palkkakustannusten alentamiseen sosiaaliturvaa leikkaamalla). Vuodesta 2002 palkkatulojen osuus BKT:sta on pudonnut 5 prosenttiyksikköä. Talouskriisin alkuvuosina Saksa onnistui säilyttämään suhteellisen korkean BKT:n kasvuvauhdin lähinnä sen ansiosta, että Kiinan massiiviset julkiset investointiohjelmat kasvattivat voimakkaasti juuri pääomahyödykkeiden vientiin erikoistuneen Saksan teollisuuden kysyntää. Kiinan talouskasvun hidastuminen onkin vaikeuttanut saksalaisten yritysten tilannetta voimakkaasti ja myös Saksan kasvu jäi vuosina 2012-13 varsin matalaksi (0,3-0,4 \%). Fratzscherin mukaan Saksan talouskehitystä uhkaa vakavasti jo pitkään olemassa ollut "investointikuilu", sillä investointien osuus BKT:sta on Saksassa pudonnut enää noin 17 prosenttiin (kun se OECD-maissa keskimäärin on noin 20 prosenttia) (Fratzscher 2014: 77). Saksalaisten yritysten pääomavarantojen arvo on laskenut vuodesta 2001 lähtien. Erityisesti Saksa on jäänyt jälkeen "immateriaalisissa" investoinneissa, esimerkiksi tutkimus- ja kehitysmenoissa tai "organisaatiopääomassa", sillä ne ovat kasvaneet huomattavasti hitaammin kuin Ranskassa, Isossa-Britanniassa saati sitten Yhdysvalloissa (Fratzscher 2014: 79). Julkisten investointien osuus oli vuonna 2011 vain 1,6 prosenttia BKT:sta, kun Euroopan unionissa kokonaisuutena se oli 2,5 prosenttia. Koulutukseen Saksassa investoidaan vain 5,3 pro- 
senttia kansantuotteesta, kun teollisuusmaissa keskimäärin luku on 6,1 prosenttia (Fratzscher 2014: 93). Matalat investoinnit ovatkin heikentäneet faktorituottavuuden kehittymistä voimakkaasti 1990-luvun alusta asti (Fratzscher 2014: 81-82).

Yksi keskeinen syy sille, miksi Saksa saattoi saavuttaa niin suuren kilpailukykyedun oli se, että niin sanotut Hartz-reformit vuosituhannen vaihteessa siirsivät merkittävän osan epäsuorista työvoimakustannuksista kotitalouksien harteille. Ylipäätään ne alensivat oleellisesti työn hintaa ja heikensivät työntekijöiden neuvotteluasemaa. Vuonna 2003 Hartz II -laki toi käyttöön niin sanotut mini-jobit, joissa työnantaja on vapautettu kaikista vakuutusmaksuista eikä työntekijällä ole minkäänlaista eläke- tai työttömyysturvaa, sekä midi-jobit, joissa palkka on 400-800 euroa. Hartz III -laissa 2004 kiristettiin voimakkaasti työttömien kontrollitoimia. Vuoden 2005 Hartz IV -laki lyhensi työttömyysetuuden keston kolmesta vuodesta vuoteen ja kiristi etuuden saamisen ehtoja (vähintään 12 kuukautta töissä 2 vuoden aikana; mikäli ehtoja ei täytä, saa vain sosiaalitukea joka on alle 400 euroa kuussa). Mini-jobeja (joissa palkka on siis korkeintaan 450 euroa kuussa) oli uudesta minimipalkkalaista huolimatta vielä vuoden 2015 lopussa noin 6,9 miljoonaa (Minijob-Zentrale 2015). Ylipäätään työtätekevät köyhät edustavat noin viidesosaa kaikista Saksan työntekijöistä.

Kun Saksan mallin mukaiset talouskurisäännöt on levitetty koko euroalueelle, ne ovat epäilemättä heikentäneet euroalueen talouskasvua ja työllisyyttä. Siksi monet ovatkin vaatineet, että euro pitäisi hajottaa tai eri maiden kannattaisi oman etunsa vuoksi erota eurosta yksipuolisesti. Ajatukseen sisältyy kuitenkin jonkinlainen rahafetisismi: raha, euro irrotetaan muista yhteiskunnallisista, tuotannon ja työn järjestämiseen liittyvistä valtasuhteista ja samalla tietyt euroalueen instituutioihin liittyvät poliittiset sopimukset samastetaan "kapitalismin" tai "talouden" lakeihin. Sen sijaan euroa, sen luonnetta epätäydellisenä ra- hana tai eräänlaisena finanssimarkkinoiden fraktiorahana olisi tarkasteltava yhteydessä laajempiin kapitalismin muutoksiin sekä muutoksiin erilaisissa hallinnan tavoissa ja mikrotason valtasuhteissa.

Raha ei ole varsinaisesti ole minkäänlainen olio eikä taloudellisen arvon representaatio vaan rahaa voidaan tarkastella ainoastaan maksujärjestelmänä, jossa keskeisin selvitettävien maksujen muoto on elävän työn ja pääoman välisten ostotapahtumien maksaminen. Nykyisin raha luodaan pääosin pankkijärjestelmässä liikepankkien myöntäessä luottoa asiakkailleen, mutta pankit eivät tietenkään voi luoda rahaa yksipuolisesti vaan ainoastaan jonkin tahon pyytäessä luottoa, eikä rahan vaikutuksia valtasuhteena voida palauttaa ainoastaan rahan luomiseen vaan sen on ulotuttava koko kiertokulkuun siihen asti, kunnes luotu raha "tuhoutuu" ja luodaan uudestaan, kun velka maksetaan takaisin (Schmitt 1966; Graziani 2003). Se, minkälaiseen taloudelliseen toimintaan luottoa myönnetään eli rahaa luodaan, riippuu kuitenkin koko tuotannon ja työn järjestämisen tavasta, sillä liikepankki odottaa, että sen myöntämä luotto maksetaan takaisin ja vieläpä korkojen kera niin, että pankki kykenee tekemään voittoa luototustoiminnallaan. Siksi luototettavien investointien täytyy kyetä kyseisen tuotantotavan piirissä tuottamaan lisäarvoa.

Millä tavoin siis euro rahana ja yhteisvaluutan luomisen prosessi on toiminut elävän työn ja pääoman välisen suhteen uudelleenjärjestämisen eli elävän työn alistamisen välineenä sekä tuotannon ja kierron alueiden välisten suhteiden uudelleenartikuloimisen välineenä? Jos raha on keskeinen elementti kapitalismissa ja konstituoi itse pääoman ja työvoiman välistä suhdetta, on kysyttävä, minkälaisia tuotantosuhteita euro rahana on rakentanut? Minkälaista työtä, minkälaisia työn alistamisen tapoja se on edistänyt? Mikäli on totta, kuten lukuisat taloustieteilijät ovat korostaneet, että euro on heikentänyt alueen talouskasvua, syynä ei ole pelkästään julkisten menojen leikkaa- 
minen sinänsä (suorien efektiivistä kysyntää vähentävien vaikutusten vuoksi) vaan seuraukset ovat olleet myös laadullisia, kuten EKP:n yllä mainitusta selvityksestä kävi ilmi. Juuri Maastrichtin sopimukseen ja Fiscal Compactiin liittyvien säädösten vuoksi euro on estänyt jäsenmaita investoimasta tarpeeksi nykytalouden keskeisiin tuotannontekijöihin, kuten koulutukseen, terveydenhuoltoon, siis ylipäätään elävään työhön, työntekijöiden ruumiin ja aivojen kokonaisvaltaiseen kehittämiseen. Nykyisin Euroopan unionin maiden suurimmat globaalit markkinaosuudet ja kilpailukykyedut ovatkin Euroopan komission mukaan erityisesti painotuotteissa ja äänitteissä, tupakkatuotteissa, alkoholijuomissa, lääkkeissä, paperissa ja autoteollisuudessa (Euroopan komissio 2013: 9). Ei siis informaatioteknologiassa, luovassa taloudessa, terveydenhuoltopalveluissa tai muilla keskeisillä kasvualoilla. Toisin sanoen aikana, jolloin arvonlisäyksen painopiste on siirtynyt teollisesta tuotannosta "ihmisen tuottamiseen ihmisen avulla" (Boyer 2004), yhteisvaluutan rakenne on heikentänyt euromaiden mahdollisuuksia investoida talouskasvun kannalta olennaisiin tuotantovälineisiin, jotka ovat yleisiä tai yhteiskunnallisia eivätkä yksityisen yrityksen sisään sijoittuvia tuotantovälineitä.

Jos innovatiivisen yritystoiminnan edellytyksenä on luoton saaminen, kuten jo Joseph Schumpeter kuvasi, euro tuntuu toimivan sitä vastaan. Euro onkin toiminut jokseenkin vastaavalla tavalla kuin kultakanta, joka pikemminkin estää innovaatioiden kehittämiseen vaadittavan luototuksen. Fiscal Compactiin liittyvät talouskurisäännöt (korkeintaan 0,5 prosentin rakenteellinen alijäämä suhteessa BKT:hen niille maille joilla julkinen velka ylittää 60 \% BKT:sta eli käytännössä kaikki keskeiset euromaat) tarkoittavat, että valtioiden täytyy ikään kuin rahoittaa itseään välittömästi juoksevilla tuloillaan. Entä jos yrityksiä kiellettäisiin ottamasta lainaa ja pakotettaisiin rahoittamaan toimintaansa ainoastaan välittömällä kassavirralla? Erityisesti tilanteessa, jossa julkiset investoinnit ovat olleet hyvin keskeisiä talouskasvun yleisten edellytysten ja myös yksittäisten innovaatioiden lähteitä, kuten Mariana Mazzucato on tarkasti osoittanut kirjassaan Entrepreneurial State, on selvää, että taloudesta ei voi tulla kovin dynaamista tai innovatiivista jos sen rahoitusmahdollisuuksia rajoitetaan tällä tavoin. Valtionvelasta korkotuloja saaville rahoituslaitoksille tilanne toki on hyvin edullinen.

Nykykapitalismissa talouskasvun ja arvonlisäyksen lähteinä ovat yleiset kyvyt, työvoima potentiana, siis yleisenä eikä erityisenä tuotantovälineenä. Toisin sanoen työntekijältä tai työyhteisöltä vaadittaisiin yksinkertaisen oppimisen, tiettyjen tehtävien oppimisen sijaan sitä, mitä Gregory Bateson kutsuu "tason 3 oppimiseksi", oppimaan oppimiseksi tai uudenlaisten oppimistottumusten kehittämisen kyvyksi. "Innovaatioiden" luomiseksi ei riitä, että pystyy oppimaan jonkin tietyn uudenlaisen kommunikaatiotavan (vaikkapa koodauskielen) vaan olisi kyettävä kehittymään uudenlaisten tottumusten omaksumisessa. Yleisesti ottaen työvoima vaikuttaakin olevan eräänlaisessa Batesonin double bindissa, jossa kommunikaation yksinkertaisten semanttisten sisältöjen tasolla kehotetaan olemaan luova, innovatiivinen, tekemään rohkeita avauksia, mutta loogisesti toisella kommunikaatiotasolla, metakommunikaatiossa käsketään vain tottelemaan, alistumaan, raatamaan kuin muuli. Euroalueella itse raha, maksujärjestelmän parametrien kautta, on toiminut tällaisena double bindia tuottavana metakommunikaatiovälineenä, joka ikään kuin viestii "luoville työläisille" ettei heidän luovuutensa kiinnosta ketään, hengissä selviämiseksi on vain raadettava ja etsittävä mitä tahansa työtä millä tahansa keinolla. Yleisiin valmiuksiin kuten koulutukseen joka ei palvele mitään välittömiä tarpeita, terveydenhuoltoon tai varsinkaan tietyistä työsuorituksista riippumattomiin rahatulon lähteisiin (jotka tekisivät elinikäisen oppimisen mahdolliseksi) ei haluta investoida, koska eurojärjestelmää jäsentävien parametrien mu- 
kaan ne ovat aina ainoastaan menoeriä, eivät investointeja.

Taustalla ei kuitenkaan ole minkäänlainen eurojärjestelmän arkkitehtien tai poliitikkojen typeryys tai epäonnistuminen vaan hyvin konkreettiset historialliset syyt, jotka liittyvät uudenlaisen, finanssivetoisen globaalin makrotaloudellisen järjestyksen sisäisiin eroihin sekä historiallisiin seikkoihin, joiden perusteella Saksan talousmalli on yleistetty koko euroalueen talouspolitiikan perustaksi.

Noin vuodesta 1945 vuoteen 1973 läntisessä Euroopassa ja Yhdysvalloissa oli olemassa fordismiksi kutsuttu regulaatiomuoto, joka liittyi teollisen kapitalismin kasautumisjärjestelmään. Fordismin keskeisiä piirteitä olivat kollektiivinen neuvottelu ja tuottavuuteen sidottu palkkataso, teollisen työn keskeinen asema arvonmuodostusketjussa sekä kansallisvaltion harjoittama pääomavirtojen ja efektiivisen kysynnän säätely (julkisten investointien sekä sosiaaliturvan kautta, eli niin sanottu keynesiläinen talouspolitiikka) (Aglietta 1997). Fordistisen regulaatiomuodon hajottua 1970-luvun loppupuolella ja 1980-luvun alussa vastaavaa säätelymuotoa ei ole ollut. Globaalilla tasolla finanssimarkkinat ovat saaneet fordismiin verrattuna huomattavan keskeisen roolin niin tuotannon kuin kysynnän organisoinnissa (ks. Marazzi 2015).

Kun tuotantoketjujen globaalistuminen ja työn järjestämisen uudet tavat (prekarisaatio) ovat heikentäneet työvoiman neuvotteluasemaa ja johtaneet keskeisissä OECD-maissa reaalipalkkakehityksen huomattavaan heikentymiseen, finanssimarkkinoiden merkitys globaalien pääomavirtojen ohjaamisessa on korostunut. Globaalin talouden sisälle on syntynyt duaalinen järjestys, jossa kysyntä on keskittynyt tiettyihin voimakkaasti finanssivetoistuneihin, kauppataseeltaan alijäämäisiin maihin (Yhdysvallat, Iso-Britannia, ennen talouskriisin alkua Etelä-Euroopan maat) ja teollinen tuotanto muutamiin suhteellisen matalien työvoimakustannusten maihin, joilla on suuret kauppataseen ylijäämät (ennen kaikkea Saksa, Kiina ja Japani). Martin Wolfin mukaan globaalin talouden epätasapaino kasvoi vuosina 1996-2006 viisinkertaiseksi tuotannon volyymin kasvu huomioon ottaen (Wolf 2014). Vuonna 1996 kauppataseeltaan ylijäämäisten maiden kokonaisylijäämä oli 298 miljardia, mistä 10 ylijäämältään suurimman maan osuus oli 228 miljardia. Vuonna 2006 ylijäämien kokonaissumma oli noussut 1527 miljardiin, mistä 10 suurimman osuus oli 1037 miljardia. Vuonna 1996 suurin ylijäämä oli Japanilla, 66 miljardia, kun vuonna 2006 Kiinan ylijäämä oli 232 miljardia, Saksan 182 miljardia ja Japanin 171 miljardia. Vuoteen 2014 mennessä Saksan ylijäämä oli noussut maailman suurimmaksi, 217 miljardiin euroon.

Fordismin kriisin jälkeen on siis syntynyt ikään kuin kaksi erilaista makrotaloudellista tuotannon järjestämisen mallia, "amerikkalainen" eli finanssi- ja velkavetoinen sekä "saksalainen" (tai yhtä hyvin japanilainen ja kiinalainen) malli. $\mathrm{Ne}$ ovat kuitenkin olleet välittömästi toisiinsa kietoutuneita siinä mielessä, että vientiteollisuusvetoiset maat ovat olleet täysin riippuvaisia finanssivetoisten alueiden kysynnästä. Globaalilla tasolla ne ovat siis muodostaneet pikemmin yhden yhtenäisen, vaikkakin kansantalouksien näkökulmasta "epätasapainoisen" järjestyksen.

Ennen finanssikriisin alkua, vuoteen 2008 asti euroalueen sisälle oli muodostunut samanlainen "epätasapaino" tai pikemminkin valtioiden rajat ylittävä taloudellinen (tosin epävakaa) järjestys, jossa teollisuus keskittyi tietyille suhteellisen matalapalkkaisille ja kilpailukykyisille alueille (ennen kaikkea Baijeri, Baden-Württenberg, Hollanti, osin Suomi) ja luottovirtojen aikaansaama kysyntä taas toisille, korkeamman inflaation alueille (erityisesti Espanja, mutta myös Kreikka, Portugali, Irlanti sekä toki Iso-Britannia), joille syntyneet kiinteistöbuumit kasvattivat kotitalouksien varallisuutta. Kärjistetysti sanottuna saksalaiset pankit lainasivat matalapalkkaisen vientiteollisuuden tuottaman kauppataseen ylijäämän espanjalaisille ja kreikkalaisille, jot- 
ka ostivat velkarahalla saksalaisia vientituotteita.

Euron luomisen erilaiset seuraukset makrotalouden tasolla aiheuttavat ongelmia, jotka purkautuvat kansainvälisten pääomavirtojen epävakautena, kun ylijäämien kiertoa ei järjestetä millään muulla tavalla kuin globaalien finanssimarkkinoiden kautta. Toisin sanoen tilanteessa, jossa vastauksena fordismin vastaisiin kamppailuihin luotu uudenlainen tuotantoketjujen rakenne sekä uudet liberaalit hallinnan tekniikat ovat vieneet työväenliikkeeltä sen perinteisen neuvotteluvoiman (kyvyn pysäyttää tuotanto tehtaan sisällä), mikään järjestäytynyt voima ei pakota pääomaa jakamaan tuloja työntekijöille, ja tämän seurauksena ainoaksi tavaksi luoda efektiivistä kysyntää ovat jääneet erilaiset finanssitulon muodot. Globaalista taloudesta on kuitenkin sen vuoksi tullut äärimmäisen epävakaa, ja se kärsii jatkuvasta kysyntävajeesta, koska suurituloiset osakkeenomistajat eivät tietenkään kuluta yhtä suurta osaa tuloistaan kuin fordistinen keskiluokka.

Itse yhteisvaluutalla oli, kuten todettu, tämän järjestyksen luomisessa keskeinen merkitys, mutta toisaalta rahapolitiikka ylipäätään on toiminut keskeisenä perinteisen työväenliikkeen instituutioiden tuhoamisen ja palkkamaltin ylläpitämisen keinona. Yhdysvalloissa siirtymä monetarismiin ja niin sanottu Volckerin käänne näyttelivät keskeistä roolia Keskilännen suurissa teollisuusyrityksissä vaikuttaneen ay-liikkeen tuhoamisessa. Lokakuussa 1979 vasta valittu Yhdysvaltain keskuspankin pääjohtaja Paul Volcker päätti nostaa ohjauskorkoa siitä huolimatta, että Yhdysvallat oli ajautumassa taantumaan. Muodollisesti perusteena toimi uusi monetaristinen rahapoliittinen doktriini, jossa ohjauskorko määräytyi rahan määrää koskevan suoran tavoitteen eikä enää korkotasoa koskevan tavoitteen perustalta. "Volckerin käänne" johti taantuman syvenemiseen ja työttömyyden voimakkaaseen kasvuun. Sen jälkeen inflaatio on 1980-luvun puolivälistä alkaen ollut keskimäärin huomat- tavasti edellisiä vuosikymmeniä matalampaa, ja syynä on nimenomaan se, että perinteinen ammattiyhdistysliike ja siten työntekijöiden neuvotteluvoima on keskeisissä OECD-maissa huomattavasti heikentynyt, minkä vuoksi palkkataso ei ole kohonnut yhtä voimakkaasti kuin aikaisempina vuosikymmeninä (Marazzi 1994). Euroa luotaessa taas juuri inflaation mataluus oli yksi keskeinen edellytys yhteisvaluuttajärjestelmään mukaan pääsemiselle. Eli toisin sanoen järjestäytyneen fordistisen työväenluokan murskaamista pidettiin edellytyksenä yhteisvaluuttajärjestelmän jäsenyydelle.

Maastrichtin sopimus allekirjoitettiin 7 . helmikuuta 1992, ja jo kesällä 1992 se johti hieman samankaltaisiin ilmiöihin kuin myöhemmin Kreikan kohdalla vuonna 2010. Hillitäkseen Saksojen yhdistämisen luomaa inflaatiopainetta Bundesbank nosti korkoja 16. kesäkuuta siitä huolimatta, että lähes koko EMU-alue oli taantumassa, ja kiinteiden valuuttakurssien järjestelmän vuoksi myös muiden maiden oli pakko nostaa korkotasoaan (tai ainakin olla laskematta sitä), mikä aiheutti niille vakavia ongelmia. Varsinkin kun Tanska oli hylännyt Maastrichtin sopimuksen kansanäänestyksessä 2. kesäkuuta samana vuonna, seurauksena oli laajamittainen spekulaatio liiraa ja pesetaa vastaan. Tämän vuoksi liira devalvoitui noin 7 prosentilla 14 . syyskuuta. Kolmea päivää myöhemmin liira joutui eroamaan EMS:stä. Samana päivänä ulos joutui myös punta, sillä liiran devalvaation seurauksena sijoittajat "hyökkäsivät" muiden heikkoina pitämiensä valuuttojen, ennen kaikkea punnan ja frangin kimppuun. Michel Agliettan mukaan episodin opetuksia ei otettu euroa rakennettaessa lainkaan tosissaan, ja seurauksena oli, että eurosta tuli lopulta eräänlainen kultakantaa tai kiinteitä valuuttakursseja muistuttava järjestelmä, joka on vieras valuutta kaikille maille paitsi Saksalle vähemmän kuin muille (Aglietta 2012: 42).

Etelä-Euroopan maissa korkotason laskiessa ja suhteellisen palkkatason samanaikaisesti noustessa ylijäämäisistä euromaista 
(ennen kaikkea Saksasta) tulevat pääomavirrat suuntautuivat ennen kaikkea kiinteistöihin. Espanjassa talous kasvoi poikkeuksellisen nopeasti vuodesta 1995 vuoteen 2007: BKT:n kasvu oli keskimäärin 4 prosenttia vuodessa, luotiin seitsemän miljoonaa uutta työpaikkaa, inflaatio säilyi matalana ja yksityinen velkaantuminen kasvoi räjähdysmäisesti. Kotitalouksien velat kasvoivatkin vuodesta 2000 vuoteen 2007 noin kolminkertaisiksi. Velaksi ostettiin tietenkin ennen kaikkea asuntoja, sillä Espanjan hallitus oli tukenut verohelpotuksin ja muilla keinoin omistusasumista jo Francon ajoista asti. Kiinteistökuplan huippuvuosina 2002-2006 asuntojen hinnat nousivat keskimäärin 30 prosenttia vuodessa. Rakentamisen huippuvuosina 2005 ja 2006 aloitettiin vuodessa yli 700000 uutta asuntoa (Lopez \& Rodriguez 2010: 190-195). Asuntojen arvonnousun ansiosta kotitalouksien varallisuus kasvoi niin voimakkaasti, että yksityinen kulutus kasvoi Espanjassa huomattavasti muita OECD-maita nopeammin (noin 91 prosentilla vuosina 1997-2007). Samaan aikaan työn tuottavuus ei kasvanut käytännössä lainkaan ja reaalinen mediaanipalkka jopa laski vuodesta 1997 vuoteen 2007 asti noin 10 prosenttiyksiköllä. Seurauksena Espanjassa tapahtui sama kehitys kuin kaikissa muissakin OECD-maissa, mutta vielä voimakkaammin: palkkatulojen osuus bruttokansantuotteesta laski voimakkaasti (Espanjassa kehitys alkoi jo vuonna 1978) ja erilaisilla omaisuustuloilla (ennen kaikkea asunnon arvonnoususta eri tavoin muodostuvilla tuloilla) oli huomattavasti aiempaa suurempi vaikutus kulutuskysynnän luomisessa. Kun eri hallitukset pyrkivät tietoisesti nimenomaan edistämään omistusasumista ja asuntojen hinnannousua, ne harjoittivat eräänlaista "keynesiläisyyttä omaisuuden arvonnousulla".

Finanssikriisin myötä pankkien luotonanto tyrehtyi, kiinteistökupla romahti ja erityisesti eteläiset euromaat joutuivat pelastamaan vaikeuksiin ajautuneita pankkeja, mikä ajoi niiden julkiset taloudet vaikeuksiin. Jäsenmaat pakotettiin leikkaamaan julkisia menoja, mikä johti romahduksen kiihtymiseen entisestään kotimaisen kysynnän heikentyessä. Talouskuritoimien ja erityisesti Fiscal Compactin seurauksena euroalueelle kokonaisuutena on täysin eksplisiittisesti yritetty levittää "Saksan mallia" eli matalapalkkaiseen vientiteollisuuteen perustuvaa mallia. Euroalueesta kokonaisuutena onkin tullut kauppataseeltaan ylijäämäinen. Vuoden 2015 toisella vuosineljänneksellä euroalueen kauppataseen vuosittaisesti laskettu ylijäämä oli EKP:n mukaan 294,4 miljardia euroa, eli 2,9 prosenttia alueen bruttokansantuotteesta .

\section{MODELL DEUTSCHLAND}

Vaikka lähes kaikki ovat yhtä mieltä siitä, että ilman Saksojen yhdistymistä Länsi-Saksa ei olisi ainakaan niin nopeasti mitä tapahtui suostunut luopumaan D-markasta, joka oli sille ranskalaisten virkamiesten sanoin "ydinpommin vastine", lopulta Saksa sai Maastrichtin sopimusta valmistelleissa neuvotteluissa läpi käytännössä kaikki vaatimuksensa. Euro rakennettiin Saksan vaatimusten mukaiseksi, ja sikäli kuin rahalla on taloudelle perustavanlaatuinen merkitys, se on toiminut modell Deutschlandille ennen kaikkea edellytyksiä rakentavana suhteena. Finanssikriisin aikana tosin itse yhteisvaluuttajärjestelmän sisälle on syntynyt eräänlainen latentti konflikti tai kahtiajako saksalaisen ordoliberaalin ja "amerikkalaisen" velkavetoista kapitalismia edustavan suuntauksen välillä.

Tarkoitukseni on tarkastella Modell Deutschlandin genealogiaa, sen globaalia ja makrotaloudellista kontekstia, siihen liittyvää tuotantomallia, hallinnan tapaa tai rationaalisuutta ja yhteiskunnallisten valtasuhteiden, ennen kaikkea työvoiman ja pääoman välisen suhteen sekä sukupuolten välisten valtasuhteiden mallia. Vaikka puhutaan "Saksan mallista" on nähdäkseni äärimmäisen olennaista päästä 
yli kansallisvaltion ja kansantalouden kehyksen sekä irti valtioiden tai kansantalouksien välisiin suhteisiin perustuvasta käsitteellisestä kehikosta. Kyse ei ole milloinkaan ollut yksiselitteisesti "Saksan edusta", sillä sellaista ei tietenkään ole yhtenäisenä etuna olemassa. Sen sijaan "Saksan mallia" on tarkasteltava osana tiettyä globaalin talouden muodostelmaa ja kapitalismin ylikansallista regulaatiomuotoa. Toisaalta on tarkasteltava itse kansantalouden muodostumista erilaisista eroista, konflikteista ja valtasuhteista. Eri instituutioilla ja eri pääoman sektoreilla on eri aikoina ollut erilaisia pyrkimyksiä ja intressejä, jotka eivät aina ole muodostaneet yksiselitteistä "Saksan etua". Siksi en tarkastele Saksan mallin enkä myöhemmän yhteisvaluutan kehitystä minkään erityisten, historiallisesti yleispätevinä pidettyjen taloudellisten tai sosiologisten kategorioiden kautta vaan pyrin käsittelemään niitä niiden historiallisessa kontekstissa, joka on yhtäältä mikropoliittinen, toisaalta globaali.

Saksassa ei ole koskaan esiintynyt fordismia sanan varsinaisessa merkityksessä, sillä Saksan talouskasvu on toisesta maailmansodasta asti perustunut jatkuvasti ennen kaikkea vientiteollisuuteen eikä kotimaisen kysynnän kasvattamiseen. Sen keskeinen kilpailuvaltti keskeisiin kilpailijamaihin nähden on lähes aina ollut suhteellisen alhaiset reaaliset työvoimakustannukset. Tämä näkyy selvästi Saksan vientiteollisuuden sektorirakenteessa, sillä kaikista suurista vientimaista Saksa on selvimmin keskittynyt tuotantovälineiden tai pääomahyödykkeiden tuottamiseen. Saksan viennistä poikkeuksellisen suuri osuus on tuotteita, joita ei markkinoida suoraan kuluttajille. Ainoastaan aivan viime vuosina euroalueen syvän kriisin johdosta Saksassa on syntynyt kotimaisen kulutuskysynnän vetämää talouskasvua. Vaikka Saksaa yleisesti pidetään erityisesti autoteollisuuden ansiosta menestyneenä maana, tosiasiassa sen autoteollisuus on toisen maailmansodan jälkeisinä vuosina rakentunut aluksi pitkälti Yhdysvalloista tuodulle teknologialle, jota käytettiin siellä palk- katason ja valuuttakurssin ansiosta matalammin kustannuksin kuin Yhdysvalloissa, kuten jatkossa tarkemmin osoitan. Nykyisin taas autoteollisuus muodostaa pikemminkin poikkeuksen suhteessa muuhun Saksan elinkeinorakenteeseen, joka on voimakkaasti keskittynyt tuotantovälineiden vientiin. Lisäksi kuten esimerkiksi Volkswagenin päästöskandaali on osoittanut, Saksan autoteollisuuden kilpailukykyä on paranneltu myös muiden kuin varsinaisesti suorituskykyä kohentavien teknisten "innovaatioiden" keinoin.

Syyt Saksan valtaville kauppataseen ylijäämille ovat siis rakenteellisia, ja niitä olisi siksi tarkasteltava historiallisesti. Saksa on yhdessä Japanin kanssa muodostanut koko toisen maailmansodan jälkeisen ajan eräänlaisen poikkeuksen suhteessa muiden OECD-maiden kysyntävetoiseen fordistiseen talousmalliin. Nyt erityisesti euroalueella näyttää siltä, että tätä mallia yritetään levittää koko alueelle. Pyrkimys on kuitenkin osoittautunut äärimmäisen vaikeaksi juuri siksi, että Saksan (ja Japanin) vientivetoinen malli on historiallisesti toiminut ainoastaan poikkeuksena, koska se on ollut riippuvainen ulkomaisesta, erityisesti Yhdysvaltain kulutuskysynnästä. Yhdysvalloille Länsi-Saksa ja Japani olivat kylmän sodan aikana (ennen kaikkea 1950-60-luvuilla) strategisesti keskeisiä liittolaisia, minkä vuoksi niiden annettiin tuoda tuotteitaan Yhdysvaltain markkinoille suhteellisen halvalla hinnalla, sillä niiden talouskasvun tukemisen nähtiin olevan olennaista niiden pitämiseksi Neuvostoliiton vastaisessa rintamassa. Modell Deutschlandin luonnetta ja sen nykyistä asemaa ei kuitenkaan voida ymmärtää ainoastaan sattumanvaraisten ja yksittäisten poliittisten käänteiden perustalta, vaan sitä on syytä tarkastella globaalien makrotaloudellisten muutosten lisäksi suhteessa työvoiman kokoonpanon, erilaisten yhteiskunnallisten voimasuhteiden ja konfliktien sekä niihin vastaavien tuotannon järjestämisen tapojen muutoksiin.

Yksittäisen kansantalouden näkökulmasta Saksan (tai muiden vientivetoisten maiden) 
valtavat kauppataseen ylijäämät ovat olleet vääjäämättömiä siinä mielessä, että jos samaan aikaan sekä palkat ja kotimainen kysyntä että julkiset menot pysyvät suhteellisen matalina, vientiteollisuuden tuotot on pakko sijoittaa ulkomaille. Mikäli rahavirtojen ohjaamiseen ei ole olemassa kansallisen tason ylittäviä talouspoliittisia rakenteita, se jää yksityisten liikepankkien tehtäväksi. Jos taas kyseisissä vientimaissa teollisuuden kilpailukyky on parempi kuin muissa maissa, ei kalliimpien tuotantokustannusten maihin kannata tehdä teollisia investointeja. Euroalueen sisällä pääomavirrat suuntautuivat esimerkiksi Espanjaan, mutta siellä palkkataso nousi erittäin voimakkaasti ja teollisuuden hintakilpailukyky heikkeni. Siksi investoinnit kohdistuivat ennen kaikkea asuntoihin ja muihin omaisuuseriin, joiden hinnannousulla ajateltiin saavutettavan spekulatiivisia tuottoja.

Laajemmin taustalla on muutos tuotantoketjun rakenteessa ja työvoiman kokoonpanossa, sillä tosiasiassa esimerkiksi fordismi tuottavuushyötyjen palkan kautta tapahtuvan jakamisen ja siten kysynnän luomisen järjestelmänä ei sekään syntynyt itsestään tai minkäänlaisesta kapitalismin sisäisestä rationaalisuudesta. Fordismi oli eräänlainen vastaus teollisen työväenliikkeen kamppailuihin. Toisin sanoen ainoastaan kiihtyneet taistelut työpaikoilla ja niiden ulkopuolella pakottivat pääoman takaamaan työntekijöille ainakin nimellisesti nousevan palkkatason tuotantorauhan takaamiseksi (ks. Gambino 1997). Teollisessa kapitalismissa tietyillä raskaan teollisuuden suurilla tehtailla (kuten Detroitin, Billancourtin tai Torinon Mirafiorin tehtaat) oli keskeinen asema tuotantoketjussa, ja niiden työntekijöillä siksi hyvin vahva neuvotteluvoima. 1970-luvulta alkaen tuotannon ulkoistaminen matalapalkkamaihin ja alihankkijayritysten verkostoihin sekä uudet työn järjestämisen tekniikat (työsuhteen prekarisaatio, tulospalkkaus jne.) ovat vieneet suurilta tehtailta niiden keskeisen aseman tuotantoketjussa ja siten heikentäneet työntekijöiden neuvotteluasemaa. Kiinan suurten tehtaiden työntekijöillä ei yksinkertaisesti ole samanlaista neuvotteluvoimaa kuin 1960-luvun General Motorsin tehtaiden työntekijöillä, minkä vuoksi Kiinaan ei myöskään ole syntynyt samanlaista kulutuskykyistä keskiluokkaa kuin Yhdysvaltoihin fordismin aikana. Tämä näkyy selkeimmin siinä, että Yhdysvalloissa kotimaisen kulutuksen suhde BKT:hen oli 1950-60-luvuilla jatkuvasti yli 60 prosenttia, kun se Kiinassa nyt on noin 34 prosenttia.

Samoin Saksassa palkkataso on 2000-luvun alun "talousihmeen" aikana laskenut. Itse asiassa nettoreaalipalkat eivät ole juuri nousseet 1990-luvun alusta ja vuodesta 2004 vuoteen 2008 ne laskivat (Brenke 2009). Niin sanotut mini-jobsit, joissa palkka on korkeintaan 450 euroa kuussa, ovat kasvaneet räjähdysmäisesti 2000-luvun alusta asti ja laman aikana vielä voimakkaammin. Vaikka viime aikoina on uutisoitu IG Metallin neuvottelemista suurista palkankorotuksista, palkat olivat keväällä 2015 2,4 prosenttia matalammalla kuin vuonna 2008 (The Economist 2.5.2015). Siksi myös Saksan teollisuus on ollut pitkälti riippuvaista ulkomaisesta kysynnästä. Vuosina 2001-2007 yksityinen kysyntä kasvoi Saksassa ainoastaan 0,2 prosenttia vuodessa, kun Espanjassa kasvu oli 3 prosenttia, Irlannissa 4 prosenttia, Ranskassa 2,1 prosenttia tai Suomessa 3,3 prosenttia vuodessa. Saksa saattoi olla"säästäväinen" ja "hyveellinen" ainoastaan siksi, että muut euromaat eivät olleet sitä.

Tässä mielessä yhteisvaluutassa itsessään ei ole mitään erityistä, euro ei ole mikään erityinen "paholaisen keksintö" vaan kyse on samanlaisista rahapoliittisista muutoksista, jotka ovat toteutuneet myös yhtä hyvin yhtäältä Yhdysvalloissa, toisaalta Japanissa ja Kiinassa. Esimerkiksi Kiinassa valuuttakurssin pitäminen keinotekoisesti matalalla (dollariostojen avulla) on merkinnyt suoraa tulonsiirtoa kuluttajilta vientiteollisuudelle (ks. Pettis 2013). Toki yhteisvaluutan parametrit sekä oman keskuspankin ja rahan luomisen mahdollisuuden puuttuminen euromailta kärjistävät näitä 
kehityskulkuja ja tekevät esimerkiksi julkisten menojen rajoittamisesta tavallaan "automaattisempaa".

Euro "kurirahana" on myös eräänlainen vastaus 1960- ja 1970-lukujen kiihtyneisiin työläistaisteluihin ja yhteiskunnallisiin liikkeisiin, jotka asettivat kyseenalaiseksi fordismille ominaisen rahan luomisen järjestelmän. Fordismissa inflaatio oli keskeinen rahapoliittinen mekanismi, joka toimi keinona "ottaa takaisin" kiertokulun alueella se, mikä palkkojen kohoamisen myötä tuotannon piirissä menetettiin (Rowthorn 1977). Toisin sanoen nimellispalkkoja voitiin nostaa, jos samalla nostettiin hintoja niin paljon, että yritysten reaaliset voitot eivät laskeneet. Keskuspankit hyväksyivät tämän järjestelyn niin kauan kuin työvoiman ja pääoman välinen suhde pysyi sillä tavoin vakaana, että inflaatio ei kohonnut liian korkeaksi vaan palkat ja hinnat nousivat tasaisesti "rinta rinnan". . Reaalipalkkojen voimakkaaseen kohoamiseen 1970-luvun alussa vastattiin nostamalla hintoja entistä enemmän, mutta lopulta inflaation voimakas kiihtyminen johti eräänlaiseen palkka-rahan uskottavuuden kriisiin. Palkkojen kohoamisen aikaansaaman korkean inflaation vuoksi palkkatyön takaaman rahajärjestelmän uskottavuus alkoi siis horjua.

Kenties vielä kiihtyneitä palkkavaatimuksia merkittävämmin fordismin palkka-rahajärjestelmää horjutti kuitenkin julkisten menojen voimakas kasvu ja Lyndon Johnsonin Great Society -ohjelma, jonka taustalla olivat esimerkiksi Yhdysvalloissa hyvin voimakkaasti mustien kansalaisoikeusliike sekä työttömien uudenlainen järjestäytyminen 1960-luvun aikana (Fox Piven \& Cloward 1971; O'Connor 1973). "Epäsuoran palkan" osuus kasvoi siis vähintään yhtä nopeasti kuin "suoran palkan", ja se pakotti keksimään jonkinlaisia keinoja laittaa julkiset menot ja siten yrityksille koituva verorasite kuriin. Greta Krippner korostaakin, että kapitalismin finanssivetoistumisen alkuperä on luonteeltaan poliittinen: finanssimarkkinoille annettiin tietoisesti yhä suurem- pi määräysvalta julkisen sektorin talouspolitiikkaan nähden juuri siksi, että virkamiehet ja poliitikot voisivat ikään kuin välttää vastuun leikkauksista ja siirtää sen "kasvottomille" finanssimarkkinoille (Krippner 2011).

Rahapolitiikan ja rahajärjestelmän tasolla vastaus julkisten menojen kasvuun on "keskuspankin autonomia", joka ei ole tarkkaan ottaen pelkästään monetaristisen opin vaan ylipäätään koko uuden finanssivetoisen rahapolitiikan ydin. Ajatus on siis irrottaa keskuspankit parlamentaarisesta ohjauksesta ja määrittää niiden keskeiseksi tehtäväksi "hintavakaus" eli inflaation rajoittaminen, mikä käytännössä tarkoittaa yhtäältä julkisten menojen, toisaalta palkkakehityksen rajoittamista. Keskuspankin autonomia oli esimerkiksi edellytys sille, että Paul Volcker saattoi nostaa korkoja syksyllä 1979 taantumasta huolimatta ja ajaa työväenliikkeen polvilleen.

Rahapoliittinen kehitys, jonka usein ajatellaan alkavan Volckerin käänteestä ja jollakin tavoin luutuvan Euroopassa lopullisesti paikoilleen Maastrichtin sopimuksen myötä, on tosiasiassa peräisin paljon kauempaa, eikä lainkaan sattumalta nimenomaan Saksasta. Uusliberaalien työvoiman hallinnan keinojen genealogia alkaa nimittäin oikeastaan jo heti toisen maailmansodan jälkeisistä vuosista, jolloin länsiliittoutuneet tekevät eräänlaisia talouspoliittisia kokeiluja häviäjävaltioissa. Kyse on Naomi Kleinin kuvaaman "shokkiterapian" varhaismuodosta jo 25 vuotta ennen Pinochetin Chileä, sillä ajatus on nimenomaan se, että sodanjälkeisessä kaaoksessa jo ennestään diktatuurien heikoiksi tekemät järjestäytyneen työväenluokan muodot voidaan helposti tuhota lopullisesti. Natsismin vanavedessä länsiliittoutuneet yrittävät siis luoda "lopullisen ratkaisun" järjestäytyneen teollisen työväenluokan ongelmaan. Bundesbank organisoidaan tätä tarkoitusta varten, ja suuri osa sen henkilökunnasta itse asiassa värvätään vanhoista natsiajan keskuspankin työntekijöistä (Marsh 1992). Näin Saksasta ja Japanista tulee eräänlaisia historiallisia poikkeuksia toisen 
maailmansodan jälkeisessä kapitalismissa, sillä niissä ei koskaan esiintynyt varsinaista fordismia nimenomaan sen vuoksi, että työvoiman kokoonpano on niissä aivan omanlaisensa, koska järjestäytynyt teollinen työväenluokka tuhotaan jo 1940-50-lukujen vaihteessa. Siksi niiden talouskasvu on aina riippuvaista ulkomaisesta kysynnästä.

Pian sodan päättymisen jälkeen työläiset alkoivat Saksassa järjestäytyä voimakkaasti, ja esimerkiksi Hampurissa perustettiin vuonna 1946 poliittisesti radikaali "vapaa sosialistinen ammattiyhdistys", jonka liittoutuneet kukistivat. Vuosina 1947-48 eri puolilla Saksaa nähtiin suuria lakkoja, joissa vaadittiin tuotantovälineiden sosialisointia. Marraskuussa 1948 länsiliittoutuneiden miehitysalueiden taloudesta vastaavat viranomaiset päättivät vastata inflaatioon alentamalla radikaalisti rahan tarjontaa, mikä nosti työttömyysasteen 4,5 prosentista (vuoden 1948 toisella puoliskolla) noin 12 prosenttiin vuonna 1950 (Brenner 2006: 68-69). Vastaavasti kuin Yhdysvalloissa 1980-luvun alussa tuloksena oli kaikkein radikaaleimpien, erityisesti kommunististen ammattiliittojen romahdus, minkä seurauksena Saksassa on koko toisen maailmansodan jälkeisen ajan ollut lähinnä hyvin konservatiivisia ammattiliittoja verrattuna muihin Länsi-Euroopan maihin. Välitön seuraus oli, että vuosina 1948-51 työn tuottavuus LänsiSaksassa kasvoi 50 prosenttia, mutta nimellispalkat vain 25 prosenttia (hyvin korkeasta inflaatiosta huolimatta). Vuoteen 1951 mennessä teollisuustyön tuottavuus oli saavuttanut 95 prosenttia vuoden 1938 tasosta, mutta palkat vain 80 prosenttia. Teollisuuden voittoaste oli vuonna 1951 siksi jopa korkeampi kuin natsiaikana (Brenner 2006: 67). 1950-luvun aikana teollisuustuotanto kasvoi keskimäärin 10 prosenttia vuodessa, BKT 8 prosenttia vuodessa ja työn tuottavuus 7 prosenttia vuodessa (Brenner 2006: 70). Samaan aikaan palkkakehitys jäi kuitenkin hyvin matalaksi. Brennerin mukaan tämä ei johtunut minkäänlaisesta sopimuksesta työvoiman ja pääoman välillä, ku- ten monissa muissa maissa vaan nimenomaan siitä, että Saksassa työväenliike oli niin heikko, ettei sitä tarvinnut kuunnella. 1950-luvun aikana yksikkötyökustannukset verrattuna kilpailijamaihin (niin Ranskaan, Italiaan, IsoonBritanniaan kuin Yhdysvaltoihin) laskivatkin noin 6 prosentilla. Seurauksena Saksan osuus maailman kokonaisviennistä miltei kolminkertaistui 7,3 prosentista 19 prosenttiin.

Ammattiliittojen kukistaminen rahapoliittisten toimien avulla johti jo heti toisen maailmansodan jälkeen siihen, että Länsi-Saksassa ei ole varsinaisesti koskaan harjoitettu keynesiläistä talouspolitiikkaa, lukuun ottamatta lyhyttä kokeilua 1970-luvun lopulla. Saksassa talouskasvu ei ole perustunut kotimaiseen kulutuskysyntään vaan jo 1950-luvun alusta alkaen vientiin. Saksassa kotimaisen kulutuksen BKT-osuus 1960-luvulla oli 50-54 prosenttia (kun samaan aikaan Yhdysvalloissa se oli 62-65 prosenttia), vuosien 1975-2000 välillä vaihtelevasti $60-64$ prosenttia. 2000-luvun aikana se putosi jälleen jopa 54 prosenttiin, mutta on talouskriisin aikana muun euroalueen kysynnän romahdettua jälleen hieman noussut (noin 58 prosenttiin) ${ }^{3}$.

Saksa nousi jo Korean sodan aikana miltei Yhdysvaltojen rinnalle maailman kokonaisviennin osuuksissa, mutta 1960-luvun alussa amerikkalaisen kysynnän heikkeneminen aiheutti myös Saksan talouskasvun hidastumisen. Saksan malli oikeastaan osoittaa, että myöskään fordismia ei voida tarkastella pelkästään kansallisena kasvuregiiminä vaan se muodosti globaalin kokonaisuuden, jossa Saksa ja Japani voivat harjoittaa poikkeuksina tiettyä vientivetoista ordoliberaalia talousmallia koska amerikkalaiset - ja jossain märin muut Länsi-Euroopan maat vaikka paljon pienemmässä mittakaavassa - ostivat näitä tuotteita. Saksassa matalaa palkkatasoa piti yllä ay-liikkeen konservatiivisen luonteen ohella tietenkin siirtotyöläisjärjestelmä, eli Gastarbeiterit, jotka huolehtivat teollisuuden mekaanisimmista ja matalapalkkaisimmista tehtävistä. 
Toinen edellytys vientiteollisuuden kilpailukyvylle on ollut matalan palkkatason ohella kuitenkin oleellisesti aliarvostettu valuutta, joka on lisännyt vientikilpailukykyä. Saksan järjestelmä toimi varsin hyvin niin kauan kuin Yhdysvallat oli valmis tukemaan sitä kylmän sodan poliittisen tasapainon nimissä eli pitämään omaa valuuttaansa yliarvostettuna ja ostamaan saksalaisia vientituotteita. Jo vuosina 1960-65 Saksan teollisuuden voitot kääntyivät kuitenkin laskuun pitkälti kilpailukyvyn heikkenemisen takia. Vuonna 1961 Yhdysvallat käytännössä painosti Saksan revalvoimaan $\mathrm{D}$-markan 5 prosentilla, minkä seurauksena Saksan vientiteollisuuden voittoaste laski 12 prosentilla vuodessa (Brenner 2006: 76). Vuonna 1969 Saksan oli taas revalvoitava $\mathrm{D}$-markkaa peräti 9,3 prosentilla. Lopullisiin ongelmiin Saksan malli ajautui, kun - pitkälti palkkavaatimusten ja julkisten menojen kasvun pakottamana - 15. elokuuta 1971 Richard Nixon päätti lakkauttaa dollarin vaihdettavuuden kultaan ja siten Bretton Woods -järjestelmän. Pelkästään vuoden 1973 aikana D-markan kurssi suhteessa dollariin nousi yli 20 prosentilla, neljässä vuodessa se kohosi niin massiivisesti, että kun dollareissa mitattuna reaaliset yksikkötyökustannukset olivat vuonna 1970 puolet Yhdysvaltain tasosta, ne olivat vuonna 1975 jo nousseet samalle tasolle (Brenner 2006: 129).

Nixonin päätös lakkauttaa dollarin vaihdettavuus merkitsi lähtölaukausta kapitalismin finanssivetoistumiselle. Toni Negri kutsui jo vuonna 1971 Potere operaio -lehdessä käännettä "epokaaliseksi", ja siitä lähtien niin valtioiden väliset suhteet kuin ennen kaikkea finanssipääoman ja teollisen pääoman välinen suhde määrittyivät radikaalisti uudelleen. Yanis Varoufakis on kuvannut kirjassaan Maailmantalouden minotauros sitä, miten Yhdysvaltain hallinto oivalsi, että Yhdysvaltojen ainoa keino säilyttää hegemoninen asemansa globaalissa taloudessa on pyrkiä tekemään itsestään finanssialan keskus ja kaappaamaan räjähdysmäisesti kasvaneet kansainväliset rahoitusvir- rat omiin finanssimetropoleihinsa (Varoufakis 2014). Samalla Nixonin päätös purkaa Bretton Woods -järjestelmä tarkoitti kuitenkin, että Yhdysvallat vei Saksalta ja Japanilta mahdollisuuden kohentaa vientiteollisuutensa kilpailukykyä järjestelmällisen aliarvostetun valuutan avulla. Tämän epokaalisen käänteen taustalla olivat niin globaalit kuin Yhdysvaltain sisäiset voimasuhteiden muutokset: yhtäältä Vietnamin sota, toisaalta kasvaneet sosiaalimenot olivat tehneet Bretton Woods -järjestelmän ylläpitämisestä hyvin hankalaa. Lisäksi, kuten Greta Krippner kuvasi, finanssivetoistuminen toimi Yhdysvalloissa (ja myöhemmin muuallakin) nimenomaan keinona päästä eroon niin tehtaan sisällä kuin sen ulkopuolella liian kiivaiksi kärjistyneistä taisteluista ja paineista korottaa palkkoja ja sosiaaliturvaa. Finanssipääomasta tuli 1970-luvun aikana uusi pääoman poliittinen muoto, siis muoto, jossa kapitalistit järjestäytyvät luokaksi voidakseen taata pääomasuhteen uusintamisen.

Myös Saksassa villit lakot olivat lisääntyneet voimakkaasti 1960-luvun lopulla ja johtaneet palkkakehityksen voimakkaaseen kiihtymiseen (vuoden 1969 lopulla lähes 10 prosentin vuosivauhtia, mikä oli noin kaksinkertainen Bundesbankin asettamaan kehykseen nähden). Toisin kuin monissa vähemmän vientiriippuvaisissa maissa fordismin aikana, tähän ei varsinkaan valuuttakurssin kohotessa voitu vastata inflaation avulla, siis nostamalla hintoja.

Palkkakehitys pysähtyi 1970-luvun aikana tuotantoketjujen globalisoinnin ja siten kansainvälisen kilpailun kasvun vuoksi myös Yhdysvalloissa (reaalipalkkojen nousu lakkasi vuonna 1973). Saksassa teollisuustyönantajat kuitenkin onnistuivat työväenliikkeen historiallisen heikkouden ansiosta erityisen tehokkaasti pitämään ammattiyhdistysliikkeen kurissa ja vuosina 1973-79 reaalipalkkojen kasvu lähes puolittui: vuosina 1969-73 reaalipalkat olivat kasvaneet jopa 6,6 prosenttia vuodessa, mutta vuosina 1973-79 vuosittainen kasvu oli enää 3,7 prosenttia. Samaan aikaan kun 
D-markan kurssi voimakkaasti kohosi, juuri ay-liikkeen kurissa pitämisen ansiosta Saksa sai kuitenkin pidettyä osuutensa maailman kokonaisviennistä Yhdysvaltain velkaantuessa rajusti ja sen kauppataseen muuttuessa voimakkaasti alijäämäiseksi. Samalla sosiaalimenojen kasvu pysähtyi vuosien 1960-75 4,8 prosentista vuodessa 2,0 prosenttiin vuosina 1975-80 (Brenner 2006: 148). Valuuttakurssien epäedullisesta muutoksesta huolimatta Saksan kilpailukyky ei vielä 1970-luvun lopulla juuri kärsinyt, koska inflaatio pysyi suhteellisen matalana. Öljykriisi kohotti Saksassa inflaatioasteen hetkellisesti jopa Yhdysvaltoja korkeammalle tasolle (vuonna 1973), mutta jo vuodesta 1974 lähtien Yhdysvalloissa inflaatio kiihtyi jopa yli 11 prosenttiin, kun se Saksassa jäi alle 6 prosenttiin. Yhdysvalloissa teollisuustyöläiset onnistuivat vastineeksi öljyn hinnan noususta vaatimaan itselleen korkeampia palkankorotuksia, joihin vastattiin taas kuluttajahintojen kohottamisella, mutta Saksassa palkankorotuksen jäivät aluksi vaatimattomammiksi, vaikka sielläkin sekä 1970-luvun ensimmäisinä että viimeisinä vuosina inflaatio oli keskimääräistä korkeampi.

Aivan 1970-luvun lopussa myös Saksassa palkankorotusvaatimukset kiihtyivät ja vuonna 1979 inflaatio nousi 5,4 prosenttiin edellisvuoden 2,54 prosentista. Tapahtuu siis eräänlainen luokkataisteluiden kierto Atlantin yli: ensin amerikkalaisten teollisuustyöntekijöiden kiihtyvät palkkavaatimukset pakottavat $\mathrm{Yh}$ dysvallat irrottamaan dollarin kytköksestään kultaan, jonka jälkeen reaalipalkkojen nousuun voidaan helpommin vastata inflaation avulla ilman suoraa konfrontaatiota työväenliikkeen kanssa. Lopulta inflaation kohoaminen yli 10 prosenttiin alkaa kuitenkin uhata itse palkkatyöhön perustuvan rahajärjestelmän perustaa, ja seurauksena on edellä kuvattu Volckerin käänne sekä työväenliikkeen kukistaminen rahapolitiikan avulla. Saksassa vastaava kehitys tapahtuu tavallaan askeleen jäljessä: 1970-luvun alussa lakot lisääntyvät suhteellisen voimakkaasti ja palkankorotuk- siin vastataan aluksi inflaatiolla, mutta ammattiyhdistysliikkeen suhteellisen heikkouden ansiosta kehitys katkeaa miltei heti öljykriisin jälkeen Bundesbankin kireän rahapolitiikan seurauksena. Yhdysvaltain työtaisteluiden aiheuttama inflaation voimakas kasvu johtaa kuitenkin siihen, että dollarin heikentyminen suhteessa D-markkaan kiihtyy entisestään ja aikaansaa yhä vakavampia ongelmia Saksan vientiteollisuudelle varsinkin, kun lakkoilu erityisesti metalli- ja painoteollisuudessa kiihtyy vuosikymmenen lopulla.

Ylipäätään Bretton Woodsin kaatumisesta lähtien modell Deutschland on ollut aina erittäin epävakaa ja Saksa on joutunyt etsimään jatkuvasti tasapainoa vientiteollisuuden kilpailukyvyn, jota valuutan vahvistuminen uhkaa, ja matalan inflaation historiallisen vaatimuksen välillä. Saksassa 1920-luvun hyperinflaation aiheuttamat traumat ja niiden perusteella rakennettu Bundesbankin mandaatti puhtaasti hintavakauden ylläpitäjänä ovat siis aiheuttaneet sen, että matala inflaatio on aina ollut rahapolitiikan keskeinen tavoite, mutta samalla juuri matala inflaatio on toiminut Dmarkan kurssia ylöspäin vetävänä tekijänä.

1970-luvun lopulla Helmut Schmidtin kanslerikaudella Saksa kokeili hyvin lyhyesti muiden maiden ohella inflaatiopolitiikkaa siis yritti viedä takaisin kierron alueella sen mikä on työläistaisteluiden vuoksi menetetty työn tai sosiaalimenojen alueella - mutta se johti vain samanaikaiseen työttömyyden ja inflaation nousuun, kuten muuallakin OECD-maissa. Schmidtin hävittyä vuoden 1981 vaalit Helmut Kohlille paluu "kuripolitiikkaan" tapahtui nopeasti, mutta jälleen se toimi ainoastaan Yhdysvaltain kauppataseen valtavan alijäämän ansiosta. Reaganin kaudella Yhdysvallat nimittäin harjoitti "maailmanhistorian massiivisinta keynesiläisyyttä" valtavien sotilaallisten investointien kautta, mikä piti yllä myös saksalaisen teollisuuden kysyntää. Samalla Volckerin kireä rahapolitiikka johti siihen, että dollarin kurssi suhteessa D-markkaan kääntyi takaisin voimakkaaseen nousuun 
ja Saksan vientiteollisuuden kilpailukyky vahvistui. 1980-luvun alkuvuosina Saksan kärkipoliitikot ja teollisuusliitot eivät ajaneetkaan yhteisvaluuttaa lainkaan niin innokkaasti kuin 1970-luvulla.

Andrew Moravciskin (1998) mukaan lopullinen käänne, joka ajaa Saksan tavoittelemaan euroa, on vuoden 1985 Plaza Accord, jonka seurauksena dollarin kurssi alkaa laskea, D-markan voimakkaasti nousta. Plaza Accordin seurauksena reaalisten tuntityökustannusten vuosittainen nousu oli Yhdysvalloissa G7-maiden matalin, keskimäärin 0,15 prosenttia, kun taas Japanissa se oli 2,9 prosenttia ja Saksassa 2,85 prosenttia (Brenner 2002: 61). Ratkaisevin tekijä oli juuri valuuttakurssi, sillä vuosina 1985-1990 D-markan arvo suhteessa dollariin kohosi 12,7 prosenttia vuodessa. Jos tarkastellaan pidempää ajanjaksoa 1985-1995, dollareissa mitattuna yksikkötyökustannukset nousivat Yhdysvalloissa 0,8 prosenttia vuodessa ja Saksassa 11,3 prosenttia (Brenner 2002: 64).

Robert Brennerin mukaan Saksan ja Japanin kilpailukykyongelmien keskeisin syy oli se, että 1980-luvulla teollisuuskapasiteetti kasvoi merkittävästi erityisesti Etelä-Koreassa ja Kiinassa samaan aikaan, kun erityisesti globaali kysynnän kasvu hidastui (Brenner 2002, 2006). Clintonin hallituksen tekemät julkisten menojen leikkaukset 1990-luvun alussa heikensivät kysyntätilannetta entisestään. Siksi vähenevästä kysynnästä alkoi maailmanmarkkinoilla yhä kovempi "nollasummakilpailu" ja valuuttakurssia alettiin käyttää yhä merkittävämmässä määrin kilpailukyvyn parantamisen välineenä. Saksojen yhdistyminen vahvisti entisestään Saksan talousmallin vientivetoisuutta, sillä se toi lisää kilpailua työmarkkinoille ja helpotti palkkatason pitämistä kurissa. Samaan aikaan yhdistymisen kanssa Kohlin hallitus leikkasi julkisia menoja Länsi-Saksassa ja Bundesbank nosti korkoja. Korkotason nousulla oli kuitenkin kaksinkertainen lamauttava vaikutus vientiteollisuudelle, sillä ensinnäkin se EMS-järjestelmän vuoksi vaikeutti myös muiden Länsi-Euroopan maiden taloudellis- ta tilannetta pakottaessaan nekin nostamaan korkoja ja heikensi siten saksalaisten vientiyritysten tuotteiden kysyntää, toiseksi se kohotti D-markan kurssia.

Jos aikaisemmin Saksan vientiteollisuuden kilpailukyvyn keskeisenä tekijänä oli ollut aliarvostettu valuutta, 1980-luvun lopulle tultaessa alkoi näyttää siltä, että aliarvostetun valuutan ja matalan inflaation yhdistelmä ei enää ollut mahdollinen. 1980-luvun aikana Saksan sisällä käytiin jatkuvaa kamppailua Kohlin hallituksen ja Bundesbankin välillä. Bundesbank piti jääräpäisesti kiinni matalan inflaation tavoitteestaan ja nosti korkoja, mikä johti myös valuuttakurssin nousuun, kun taas Kohl vaati kilpailukyvyn nimissä valuutan arvonnousun pysäyttämistä löysäämällä rahapolitiikkaa (ks. Marsh 2009). Vaikka Bundesbank on ollut Saksassa vaikutusvaltainen instituutio, jolla on historiallisista syistä ollut huomattavasti vahvempi autonomia ja mandaatti kuin muilla keskuspankeilla, kyse ei ollut pelkästään kahden instituution välisestä ristiriidasta. Löysemmän rahapolitiikan ja matalamman valuuttakurssin "puolella" olivat ennen kaikkea teollisuustyönantajat, jotka ovat myöhemmin kuuluneet Saksassa kaikkein äänekkäimpiin euron kannattajiin. Sen sijaan Bundesbankin takana olivat perinteiset saksalaiset pankit, vakuutusyhtiöt ja tietenkin säästäjät, joiden kannalta korkotason kohoaminen oli edullista.

Tästä näkökulmasta rahaliitto näytti ainoalta keinolta, jonka avulla Saksa saattoi 1990-luvun alussa säilyttää sekä suhteellisesti matalamman valuuttakurssin verrattuna keskeisiin kilpailijamaihin että korkeamman korkotason tai matalamman inflaation kuin muutoin olisi ollut mahdollista. Esimerkiksi Jacques Sapir on myöhemmin "syyttänyt" euroa juuri siitä, että euroalueella korkotaso on ollut Saksan kannalta liian korkea ja EteläEuroopan maiden kannalta liian matala (niin että se on edistänyt spekulatiivisia sijoituksia) (Sapir 2012: 16-17). Saksan sisällä euro kuitenkin mahdollisti, aivan kuten Sapir itse korostaa, samaan aikaan sekä eläkerahastojen 
ja ikääntyvien säästäjien talletusten arvon ylläpitämisen korkeamman korkotason ansiosta että vientiteollisuuden kilpailukyvyn parantamisen, kun palkkakehitys pysähtyi eivätkä naapurimaat enää voineet kilpailla devalvaation avulla.

Euro toimi siis Saksan sisällä keinona sovittaa yhteen teollisuuspääoman ja finanssipääoman intressit, ja hieman samalla tavoin kuin Yhdysvalloissa 1970-luvun lopulla uudessa rahapolitiikassa on jollain tavoin kyse pääoman uudesta järjestäytymisestä finanssipääoman ympärille. Sapir (2012: 30) korostaakin, että Saksan talous on tosiasiassa finanssivetoistunut hyvin voimakkaasti 1990-luvulta alkaen ennen kaikkea siksi, että ikääntyvän väestön valtavien eläkesäästöjen hoitamisesta on tullut hyvin keskeinen sektori Saksan taloudessa. Eläkerahastojen kannalta kireä rahapolitiikka oli siis keskeistä, mutta se uhkasi jatkuvasti nostaa D-markan kurssia vientiteollisuuden kannalta epäedullisella tavalla. Euro näyttäytyi keinona sovittaa nämä kaksi tavoitetta yhteen: sen ansiosta pankit ja eläkerahastot saivat kireän rahapolitiikan, vientiteollisuus aliarvostetun valuutan.

Tietenkään yhteisvaluutan luominen sinänsä missä tahansa muodossa ei välttämättä olisi ollut edullista Saksan kannalta. Kuten tunnettua, Ranskassa D-markkaa kutsuttiin "Saksan ydinaseeksi", ja itse D-markan vakaudella oli keskeinen merkitys Saksan liittotasavallan poliittisessa legitimiteetissä. 1980-luvun lopulla esimerkiksi Bundesbank näki asemansa kuitenkin vahvasti uhattuna ja monet Bundesbankin korkeat virkamiehet näkivät euron keinona "pelastaa" keskuspankin autonomia eurooppalaisella tasolla, kun se ei Saksan sisällä enää näyttänyt mahdolliselta erilaisten rahapolitiikan löysentämisvaatimusten keskellä.

Maastrichtin sopimusta koskevissa neuvotteluissa Saksa sai lopulta läpi käytännössä kaikki vaatimuksensa ja yhteisvaluutta rakennettiin D-markan ja Bundesbankin mallin mukaiseksi. Neuvottelujen voimasuhde näkyy jo valuutan nimessä ja keskuspankin sijoituspaikassa: Ranska olisi halunnut valuutan nimeksi "ecun" ja keskuspankin sijantipaikaksi Brysselin (tai Pariisin), mutta keskuspankki sijoitettiin Saksan finanssikeskukseen Frankfurtiin ja valuutta sai Saksan vaatimusten mukaisen nimen. Olennaisempia olivat kuitenkin itse raha- ja maksujärjestelmän luonnetta sekä valuuttaunionin jäsenyyskriteerejä koskevat päätökset. Jäsenyyden edellytyksenä olevien "konvergenssikriteerien" kohdalla Saksa vaati makrotaloudellista konvergenssia (eli julkisen talouden menojen leikkauksia) ennen jäseneksi hyväksymistä, keskuspankkien autonomiaa ja täyttä pääomaliikkeiden vapauttamista. Sekä Ranska että komissio vastustivat näiden asettamista jäsenyyden ehdoiksi, mutta lopulta Saksan kanta voitti. Saksa sai pääosin tahtonsa läpi myös aikataulun ja siirtymämenettelyn osalta (hitaampi aikataulu, jäseneksi valinta automaattisesti konvergenssikriteerien pohjalta, heikko keskuspankkia edeltävä EMI-organisaatio). Keskuspankin malli ja mandaatti rakennettiin täysin Saksan vaatimusten mukaan: täysi autonomia, tiukka inflaationvastainen mandaatti. Ranska ja komissio olivat halunneet, että keskuspankki olisi jollain tavoin poliittisesti ohjattavissa ja sen mandaatissa painotettaisiin muitakin tekijöitä. (Moravscik 1998: 380-386.)

Vaikka nykyisin Schäuble on väläytellyt ajatuksia "protestanttisesta eurosta", josta Etelä-Euroopan maat heitettäisiin ulos, 1990-luvun alussa Saksan teollisuus halusi Italian välttämättä mukaan rahaliittoon, koska pelkäsi että itsenäisen liiran kurssi tulisi laskemaan voimakkaasti ja veisi markkinat saksalaisilta vientiyrityksiltä. Saksan teollisuustyönantajille euro näytti siis keinolta luoda laajat markkinat omille tuotteilleen ja siten taata kysyntä samaan aikaan, kun omien työntekijöiden palkkoja pyrittiin alentamaan.

Neuvotteluja ja niiden tuloksena syntyneitä yhteisvaluutan parametreja on kuitenkin harhaanjohtavaa tulkita pelkästään kansallisten etujen näkökulmasta. Pikemminkin 
"Saksa" edustaa tässä tiettyä jälkifordistista talousmallia, jossa teollisia investointeja ja tuottavuushyötyjen jakamista keskeisempiä ovat pääomaliikkeiden vapauttaminen sekä vientiteollisuuden kilpailukyvyn parantaminen palkkojen kurissa pitämisen kautta.

Minkälaisia tekijöitä kehityksen taustalla sitten on?

Robert Brenner tulkitsee 1970- ja 1980-lukujen kehitystä ennen kaikkea pääomien välisen kansainvälisen kilpailun ja voiton suhdeluvun laskun näkökulmasta, mutta ei varsinaisesti pysty selittämään näitä ilmiöitä kovin täsmällisesti. Siksi kysymystä voiton suhdeluvusta ja pääoman kansainvälisestä rakenteesta olisi nähdäkseni lähestyttävä myös elävän työn ja pääoman välisen suhteen sekä tuotannon ja kiertokulun välisten suhteiden tietyn historiallisen muodon näkökulmasta. Ensinnäkin Nixonin päätös irrottaa dollarin kytkös kultaan ja hajottaa Bretton Woods -järjestelmä on hyvin selkeästi vastaus yhtäältä Yhdysvalloissa kiihtyneisiin työtaisteluihin ja palkankorotusvaatimuksiin, julkisten menojen kasvattamista vaatineisiin yhteiskunnallisiin liikkeisiin sekä kolmanneksi tietenkin Vietnamin sodan vastustamiseen ja muihin anti-imperialistisiin kamppailuihin. Toiseksi myös 1980-luvun uudenlainen käänne Yhdysvalloissa kohti vientiteollisuuden tukemista on myös eräänlainen seuraus siitä, että sen jälkeen kun Volcker ja Reagan ovat onnistuneet tuhoamaan vahvan ay-liikkeen ja pysäyttämään reaalipalkkojen kehityksen, he alkavat havaita, että joko amerikkalaisen teollisuuden kilpailukykyä on kyettävä jollain tavoin parantamaan tai sitten se on ajettava kokonaan alas ja oltava valmiita työttömyyden huomattavaan kasvuun. Plaza Accordin ja dollarin kurssin alentamisen taustalla on siis paradoksaalisesti monetaristisen hyökkäyksen onnistuminen. Seurauksena taas toisella puolen Atlanttia Saksan vientiteollisuus ajautuu dollarin kurssin laskiessa ongelmiin, ja tähän on vastattava uudenlaisilla rahapoliittisilla toimenpiteillä.

Niin Yhdysvalloissa kuin Saksassa voidaan havaita pääoman järjestäytyvän poliittisesti uudenlaisella tavalla. Yhdysvalloissa 1970-1uvun loppua kohden myös teollisuustyönantajat tulevat Leo Panitchin ja Sam Gindinin mukaan siihen lopputulokseen, että ainoastaan finanssimarkkinoiden ja globaalien pääomavirtojen säätelyn purkaminen sekä kireä rahapolitiikka, jonka avulla ammattiliitot voidaan hajottaa, voivat enää pelastaa teollisuuden voittoasteen (Panitch \& Gindin 2002: 163-). Periaatteessa korkotason nousun olisi siis pitänyt olla haitallista teollisuuspääomalle, koska se teki investoinneista kalliimpaa, mutta tilanteessa, jossa työvoiman neuvotteluvoima oli kasvanut liian suureksi, investointeja ei kuitenkaan kannattanut tehdä. Pääoman vallan turvaamiseksi ainoa vaihtoehto oli "järjestäytyä" uudelleen luokaksi, tällä kertaa finanssipääoman, Wall Streetin alaisuudessa. Kyse ei siis ollut pelkästään voiton suhdeluvun tendenssimäisestä laskusta - vaikka erityisesti 1970-luvun aikana teollisuusyritysten voiton suhdeluku laski selkeästi Yhdysvalloista - vaan nimenomaan vallasta, työvoiman alistamisesta. Finanssivetoistuminen on tietenkin johtanut siihen, että rahoitusala on niin Yhdysvalloissa kuin muuallakin onnistunut ottamaan haltuunsa huomattavasti aiempaa suuremman osan yritysten kokonaisvoitoista (ennen finanssikriisiä jopa 40 prosenttia ja nyt osuus on jälleen kohonnut yli 30 prosenttiin) ja siinä mielessä jopa alentanut teollisuusyritysten varsinaisesta tuotannosta saamia voittoja, mutta se on ollut ainoa keino, jolla pääoma on voinut "pelastautua" tuotantolaitosten sisällä liian kireiksi muuttuneista konflikteista.

Siksi Brennerin näkökulma, jossa Saksan teollisuuden ongelmia tarkastellaan pelkästään kansainvälisten pääomien välisen kilpailun ja voiton suhdeluvun laskutendenssin näkökulmasta, ei näytä riittävän selittämään viime vuosikymmenten muutoksia. Niitä olisi tarkasteltava pikemminkin työn ja pääoman välisen voimasuhteen sekä sitä konstituoivien muiden yhteiskunnallisten valtasuhteiden muokkautumisen näkökulmasta. Pelkästään pääomien välinen kilpailu ei riitä kapitalismin makrota- 
loudellisten muutosten selittämiseksi vaan on tarkasteltava myös lisäarvon suhdelukua eli työvoiman ja pääoman välistä valtasuhdetta.

\section{MINKÄLAISEN "MALLIN"}

\section{SAKSA ANTAA EUROOPALLE?}

Saksan talousmalli voidaan siis vetää yhteen seuraavasti: ei tuottavuushyötyjen jakamista eikä tuottavuutta kasvattavia investointeja työntekijöille vaan kilpailu vientimarkkinoista matalien palkkojen kautta sekä erikoistuminen tuotantovälineiden (pääomahyödykkeiden) tuotantoon sekä autoteollisuuteen. Kenellekään ei ole epäilystä, että euroalueella jatkuvasti vaaditut "rakenteelliset uudistukset" tarkoittavat uusia tehokkaampia työvoiman alistamisen ja työvoimakustannusten alentamisen tapoja. Viimeaikaisten tapahtumien perusteella näyttää myös, että Saksan kilpailuvalttina on palkkojen polkemisen lisäksi ollut ympäristöstandardien kiertäminen. Noin vuodesta 2011 alkaen tätä mallia on yritetty levittää koko euroalueelle niin sanotun Fiscal Compactin kautta, ja seurauksena koko euroalueen kauppatase onkin tällä hetkellä lähes kolme prosenttia ylijäämäinen.

Marcel Fratzscherin (2014) mielestä Saksan erikoistuminen juuri tietyille teollisuudenaloille, jotka eivät ole erityisen kuluttajavetoisia eivätkä perustu innovaatioihin, saattaakin tulevaisuudessa tuottaa Saksan taloudelle vakavia ongelmia. Volkswagenskandaalin yhteydessä taas esimerkiksi Martin Wolf on huomauttanut, että liiallinen erikoistuminen autoteollisuuteen näyttää juuri nyt Saksan kannalta suurelta ongelmalta. Ongelmat ovat vuodenvaihteessa 2015-16 näkyneet esimerkiksi siinä, että yritysten luottamusta talouden tulevaisuuteen mittaavat indeksit ovat laskeneet jatkuvasti. Jos aikaisemmin on kenties kuviteltu, että Saksan talous on innovatiivinen ja teknologisesti kehittynyt, Audin,
BMW:n ja Mercedeksen ympärille muodostunut "ihme", nyt tämä Wirtschaftwunder näyttää pelkältä Wunderbaumilta, jonka nostalginen tuoksu ei riitä peittämään väärin mitattujen päästöjen ja investointivajeen aiheuttamien talousongelmien käryä.

Saksan talousmalliin on aina liittynyt kiinteästi tietty sukupuolten välisen työnjaon muoto. Saksassa lastenhoidon ja kotityön (työvoiman uusintamisen) sekä sosiaaliturvan järjestämisen muoto on koko toisen maailmansodan jälkeisen ajan ollut erittäin perhekeskeinen, familialistinen. Gösta EspingAndersenin kuuluisassa hyvinvointiregiimien mallissa Saksa edustaa juuri "konservatiivista" tai familialistista mallia (Esping-Andersen 1990). Sille ominaista on pyrkimys ulkoistaa edelleen mahdollisimman suuri osa työvoiman uusintamisesta koituvista kustannuksista perheen eli naisen ilmaiseksi tekemän kotityön piiriin (ja todennäköisesti juuri siksi naisten kotityön riistoa koskeva feministinen tutkimus on 1970-luvulta alkaen kehittynyt hyvin voimakkaasti Saksassa). Koska DDR:ssä naisten työssäkäynti oli yleisempää, Saksojen yhdistyminen kohotti naisten työssäkäyntiastetta, mutta vielä vuonna 1990 Länsi-Saksassa naisten työssäkäyntiaste (labour force participation rate) oli vain 43 prosenttia, kun se esimerkiksi Suomessa oli 59 prosenttia, Ruotsissa 62 prosenttia tai Yhdysvalloissa 56 prosenttia (lähde Maailmanpankki ${ }^{4}$ ).

Kehitys ei ollut lainkaan sattumanvaraista, sillä kuten Foucault ordoliberalismia käsittelevillä luennoillaan kuvasi, ordoliberaaleille yhteiskunnan markkinamuotoistamisen tai yritysmuotoistamisen tavoitteena oli nimenomaan perheen ja perheen piirissä elävän itsenäisen yksilön (eli ennen kaikkea valkoisen miehen) arvon palauttaminen (Foucault 2004). Yhteiskuntapolitiikkaa tai sosiaalipolitiikkaa oli muokattava sillä tavoin, että valtio ei takaa palveluita tai eläketurvaa vaan yksilölle luodaan mahdollisimman kattavat mahdollisuudet hankkia itsensä ja perheensä tarvitsemat palvelut markkinoilta. Ordolibe- 
raalissa mallissa keskeinen yksikkö ei varsinaisesti ollut yksilö sanan liberaalissa mielessä vaan nimenomaan perhettä elättävä mies, jonka "yksilöllisyyteen" vaimo pikemminkin sisältyi. Länsi-Saksassa niin finanssipolitiikka kuin rahapolitiikka tähtäsivät siihen, että hyvinvointipalveluita ei järjestetä julkisina palveluina vaan perhekohtaisesti yksityisessä järjestelmässä. Saksan Hartz-reformeilla vuosituhannen vaihteessa oli täsmälleen sama vaikutus: työvoiman uusintamiskustannusten siirtäminen jälleen enemmän kotitalouksien harteille. Sikäli kuin eurojärjestelmän rakenne on nimenomaan pakottanut leikkaamaan julkisia menoja ja esimerkiksi Suomessa johtanut merkittäviin päivähoidon leikkauksiin, euro näyttää siis olevan keino pyrkiä jälleen ulkoistamaan aiempaa suurempi osa seuraavan työläissukupolven tuottamisesta pääomalle koituvista kustannuksista "perheen" piiriin, käytännössä tietenkin naisten harteille. Onko euro siis luonteeltaan "perinteisten perhearvojen" palauttamista edistävä valuutta? Eikö perussuomalaisten kannattaisi nimenomaan kannattaa yhteisvaluuttaa?

Kuten Foucault'n ordoliberalismin kuvauksesta käy ilmi yhteiskuntapolitiikan tarkoituksena ei ollut varsinaisesti "markkinoiden vapauttaminen" vaan edellytysten luominen koko yhteiskunnan yritysmuotoistamiselle puuttumalla ankarasti kaikkiin muihin elämän osa-alueisiin paitsi markkinoihin. Niin ordoliberaalien kuin amerikkalaisten uusliberaalien tavoitteena on muuttaa työntekijä"oman itsensä yrittäjäksi”, joka kantaa kapitalistin puolesta tuotannon riskit, koska hän ei enää saa palkkaa ennalta sovitusta työajasta tai työsuorituksista vaan hänen tulonsa on tuottoa hänen omalle inhimilliselle pääomalleen. Työntekijän on siis kustannettava itse koulutuksensa, eläkkeensä, terveydenhuoltonsa ja tarkasteltava tulojaan tuottona näille investoinneille. "Oman itsensä yrittäjä" on jälkifordistinen työläisen hahmo, joka itse asiassa toteutuu varsin täydellisesti amerikkalaisen subprime-lainanottajan ohella Hartz-reformien tuottamissa "minityöläisissä".
Siksi jos euro ei ole kasvattanut "työllisyyttä" sanan perinteisessä merkityksessä (toistaiseksi voimassaolevina työsuhteina joiden palkka olisi jollain tavoin sidottu tuottavuuteen), kyse ei kenties olekaan epäonnistumisesta. Saksassa vuodesta 1991 vuoteen 2010 täysipäiväisessä vakituisessa työsuhteessa olevien määrä laski 3,8 miljoonalla, kun taas erilaiset epätyypilliset työsuhteet - jotka tarkoittavat pidemmällä tähtäimellä sitä, että työntekijä on itse vastuussa tulonhankinnastaan - lisääntyivät 3,5 miljoonalla (Destatis 2012). Lisäksi myös"vakituisen" työntekijän on nykyisin oltava huomattavasti aiempaa "yrittäjämäisempi", valmis ottamaan riskejä ja investoimaan itseensä. Kenties euron ei - kaikista julistuksista huolimatta - olekaan ollut edes tarkoitus kasvattaa työllisyyttä vaan yritteliäisyyttä. Toisin kuin fordismin ajan teollisuustyöläisten muodostama keskiluokka, "oman itsensä yrittäjien" muodostama paarialuokka ei kuitenkaan kykene takaamaan efektiivistä kysyntää yritysten tuotteille. Siksi euroalue kokonaisuudessaan on täysin riippuvainen viennistä ja taloudeltaan hyvin epävakaa.

Foucault ei tarkassa ordoliberaalin diskurssin analyysissaan kuitenkaan juuri tarkastele sitä, miten perustava merkitys rahalla ja rahapolitiikalla oli ordoliberalismille. Foucault osoittaa sen, miten perustava merkitys taloudella oli Saksan liittotasavallan rakentamiselle: tilanteessa, jossa valtion olemassaololla ei ollut natsismin ja toisen maailmansodan seurauksena enää aiemman kaltaista juridista tai historiallista legitimiteettiä (ei ollut selvää millä tavoin liittotasavallan olemassaolo jatkaa aiempaa Saksan valtion olemassaoloa), taloudesta, talouskasvusta tuli koko valtion legitimiteetin perusta. Rahalla, D-markan arvon vakaudella, inflaation mataluudella oli tässä keskeinen asema, sillä juuri se toimi merkkinä siitä, että valtio onnistui toteuttamaan tehtävänsä eli takaamaan edellytykset markkinoiden toiminnalle ja yksilöiden vaurastumiselle (ks. Aglietta \& Brand 2014: 25-26).

Saksassa perustuslaki ja sen kunnioittamista valvova Karlsruhen perustuslakituo- 
mioistuin asettavat"ordon", jonka piirissä niin kansallisen kuin eurooppalaisen lainsäädäntövallan on rajoituttava toimimaan, sillä tämä markkinoiden ehtoja muodostava oikeus on ikään kuin suoraan saksalaisen keskiluokan moraalin ilmaus ja suoraan valtion legitimiteetin perusta. Euroalueen kehitystä koskevissa katsauksissa törmätäänkin nykyisin jatkuvasti Jacques Delorsin hokemaan vuodelta 1992: "Kaikki saksalaiset eivät usko Jumalaan, mutta jokainen saksalainen uskoo Bundesbankiin." Siksi ordoliberalismissa raha on markkinatalouden ja tuotannon järjestämisen perusta, kapitalismille perustava sosiaalinen side (Aglietta \& Brand 2014: 25-26). Rahan vakaus on suorastaan perustuslain takaama poliittinen tavoite vielä aivan toisella tavalla kuin esimerkiksi Yhdysvalloissa.

Bundesbankilla oli Saksan liittotasavallassa hyvin erityinen asema, sillä aina yhdistymiseen asti Bundesbank teki oman potentiaalista kasvua ja tuotantokapasiteetin kehitystä koskevan arvionsa ja sen pohjalta antoi kehyksen palkkaneuvotteluille ja hinnanmuodostukselle määrittämällä normin hintatason yleiselle kehitykselle tietyllä (palkkaneuvottelujen) ajanjaksolla (Aglietta \& Brand 2014: 25-26). Niin työntekijä- kuin työnantajaosapuolen tiedossa oli, että mikäli palkkavaatimukset tai hintojen korotukset eroaisivat tästä kehyksestä, Bundesbank tekisi kaikkensa rajoittaakseen kokonaiskysynnän kohoamista niin, että syntyisi inflaatiopaineita. Vahvasti autonominen keskuspankki siis käytännössä sääteli niin palkka- kuin hintatason kehitystä oman mandaattinsa pohjalta.

Myöhemmin vastaava poliittinen konstituutio siirtyy Euroopan unioniin ja erityisesti rahaliittoon, jotka rakentuvat pelkästään talouden perustalle, eivätkä siis oikeastaan ole poliittisia vaan pelkästään taloudellisia yhteisöjä. EKP:n mandaatti ja asema rakennetaan hyvin puhtaasti Bundesbankin mallin mukaan. Euro näyttääkin olevan juuri tällainen "yhteiskuntapoliittinen" valuutta, jolla ei ole sidettä minkäänlaiseen parlamentaariseen legitimi- teettiin vaan sen uskottavuus rahana perustuu epämääräiseen moraaliseen kuriin, jota pidetään yllä rahaliiton sopimuksiin sisältyvien talouspoliittisten parametrien kautta. Agliettan, Andreaun ja Anspachin (1998) mukaan rahaan kohdistuvalla luottamuksella on kolme muotoa: hierarkkinen, metodinen ja eettinen. Keskuspankkirahan hyväksyttävyys perustuu periaatteessa hierarkkiseen luottamukseen, siihen että valtio hyväksyy verojen maksuna ainoastaan sen itsensä liikkeelle laskemaa rahaa. Sen sijaan liikepankkien luoman rahan hyväksyttävyys käytännössä perustuu metodiseen tai proseduraaliseen luottamukseen, siihen että raha näyttää jokapäiväisessä toiminnassa tehokkaasti käyvän aina maksuna eteenpäin. Agliettan et al. (1998) mukaan näiden molempien perustana on kuitenkin "eettinen" luottamus, joka perustuu rahaa liikkeelle laskevan valtion legitimiteettiin. Bundesbankin ja myöhemmin EKP:n kohdalla legitimiteetti on saanut kuitenkin hyvin toisenlaisia muotoja kuin kansallisten valuutoiden, sillä toisin kuin jopa Federal Reserve tai muut modernit keskuspankit, Bundesbank ei Saksan perustuslain eikä EKP Maastrichtin sopimuksen mukaan ole millään tavoin tilivelvollinen parlamentaarisille instituutioille. Siksi sen luomaan rahaan kohdistuvassa luottamuksessa puhtaasti moraalisilla tekijöillä on poikkeuksellisen keskeinen rooli. Eettisten syiden lisäksi D-markkaan ja Bundesbankiin kohdistuvan yleisen luottamuksen yhtenä perustana oli epäilemättä myös se, että niiden oletettiin säilyttävän palkansaajien säästöjen reaalinen arvo. Joka tapauksessa luottamuksen perusta oli eräänlaisen "talouskurin" ylläpitäminen ja matala inflaatio.

\section{EURO FRAKTIONAALISENA RAHANA}

Agliettan näkökulmasta vaikuttaa siis siltä, että kun euron uskottavuutta tai luotettavuutta rahana ei takaa minkäänlainen poliittinen yhteisö vaan euro on vain tiettyjen yhteiskun- 
nallisten fraktioiden, tiettyjen pääoman segmenttien välisen kiistan kohde (ennen kaikkea Draghin edustama globaali finanssipääoma ja toisaalta saksalainen vientiteollisuus), sen legitimiteetin takaamiseksi on jatkuvasti vedottava epämääräisiin moraalisiin argumentteihin.

Jos tarkastelemme lähemmin euron materiaalista rakentumista valuuttana, eri fraktioiden välisen kiistan lisäksi se tavallaan halkeaa myös suhteessa eurooppalaiseen ja kansalliseen tasoon. Kuten esimerkiksi Aglietta (2012) ja Sapir (2012) ovat korostaneet, euro ei varsinaisesti ole jäsenmaille yhteinen valuutta vaan niille kaikille vieras valuutta (paitsi ehkä Saksalle vähemmän kuin muille). Tässä mielessä euro vastaa täydellisesti Euroopan unionin yleistä konstituutiota, jossa kansallista tasoa ei varsinaisesti koskaan ylitetä tai hajoteta, vaan se jää aina jäljelle, mutta jollakin tavoin muokkautuneena ja tietyt tehtävänsä menettäneenä. Talouspolitiikan alueella näyttää siltä, että Euroopan unionissa ainoastaan pääomien ja korkeapalkkaisten työntekijöiden liikkuvuus on vapautettu, Unioni toimii lähinnä pääomien liikettä kansallisista rajoituksista vapauttavana instituutiona, jossa työvoiman hallinta on jätetty kansalliselle tasolle. Oikeastaan Unionilla on varsinaisesti ainoastaan kaksi ylikansallista instituutiota: raha ja rajat. Näistä rajat on pystytetty takaisin heti, kun niitä ovat alkaneet ylittää muutkin kuin kovapalkkaiset "huippuosaajat" (jo ennen viimeisintä turvapaikanhakijoiden määrän aiheuttamaa"kriisiä" on itäeurooppalaisten romanien liikkuvuutta rajoitettu voimakkaasti Länsi-Euroopan maissa). Myöskään raha ei tosiasiassa ole varsinaisesti ollut kaikille rahaliiton jäsenmaille samalla tavoin ylikansallinen valuutta, kuten Kreikan tilanne kesällä 2015 näytti. Heinäkuun alussa 2015 EKP antoi bulgarialaisille pankeille mahdollisuuden lainata euroja suoraan EKP:sta sopivia vakuuksia vastaan samaan aikaan, kun se oli evännyt kreikkalaisilta pankeilta tämän mahdollisuuden Tsiprasin hallituksen kieltäydyttyä uuden "apupaketin" ehdoista. Toisin sanoen EKP tarjosi ei-jäsenmaan (Bulgarian) pan- keille tavallisesti vain jäsenmaiden pankeille myönnettävää keskuspankkirahoitusta, mutta samaan aikaan vei tämän mahdollisuuden jäsenmaan pankeilta, koska jäsenmaa ei noudattanut euroryhmän ja Troikan asettamia talouskurivaatimuksia (ks. Coppola 2015).

Jos raha on ensisijaisesti maksujärjestelmä, euro on Sergio Rossin mukaan varsinaisesti ylikansallinen valuutta ainoastaan yksityishenkilöille ja yrityksille, mutta ei julkisille talouksille (Rossi 2013). Jäsenmaiden keskuspankkien välisessä TARGET2-maksujärjestelmässä maiden välisiä maksuja ei nimittäin varsinaisesti selvitetä keskuspankkien, vaan ainoastaan yksityisten maksajien välillä, ja tässä mielessä euro ei valtioiden välillä periaatteessa toimi rahana vaan velkasitoumuksena. Kun yksityishenkilö tai yritys $\mathrm{X}$ maksaa rahalla tuotteen $\mathrm{A}$, hän ei tietenkään jää enää velkasuhteeseen tuotteen myyjälle. Rossin mukaan eurojärjestelmässä tilanne on kuitenkin se, että kun esimerkiksi suomalainen yksityishenkilö ostaa tuotteen saksalaiselta yritykseltä, vähennetään hänen tililtään suomalaisessa liikepankissa tuotteen hinta y, minkä jälkeen liikepankki ilmoittaa Suomen pankille ulkomaisesta maksusta saksalaiseen liikepankkiin. Suomen pankki vähentää vastaavan summan liikepankin keskuspankkitililtä ja ilmoittaa maksusta Bundesbankille, joka kirjaa summan saksalaisen liikepankin keskuspankkitilille ja liikepankki puolestaan yrityksen tilille. Seurauksena keskuspankkien väliseen maksujärjestelmään jää kuitenkin lopullisesti "selvittämätön” Bundesbankin saatava Suomen pankilta. Niin kauan kuin maiden välinen maksuliikenne pysyy tasapainossa (edes sillä tavoin että esimerkiksi saksalainen pankki tai rahoituslaitos ostaa velkakirjoja suomalaisilta toimijoilta), saatavia ei jää TARGET2-järjestelmään, mutta mikäli näin ei käy, järjestelmään muodostuu pysyvä velkasuhde maiden välillä. Näin ei tavallisesti tapahdu saman valuutan sisällä: jos esimerkiksi kalifornialainen yritys ostaa tuotteita newyorkilaiselta yritykseltä, ei alueellisten keskuspankkien välille 
muodostu minkäänlaisia velkasuhteita Federal Reserven maksujärjestelmässä.

Tämä tarkoittaa Rossin mukaan, että euro on "yhteinen valuutta" ainoastaan nimellisesti, mutta ei reaalisesti, ja itse maksujärjestelmän rakenteelliset piirteet ovat kärjistäneet jäsenmaiden välisiä kauppataseen epätasapainoja. $\mathrm{Ne}$ ovat samaan aikaan sekä luoneet äärimmäisen tuottoisia sijoitusmahdollisuuksia finanssipääomalle että tehneet mahdolliseksi kilpailuttaa maiden välillä alaspäin niin suoria kuin epäsuoria palkkoja (eli sosiaalimenoja). Kuten lukuisat keynesiläiset tai postkeynesiläiset taloustutkijat ovat korostaneet, euron ongelma on olla "valuutta vailla valtiota" ja euromaiden taas valtioita vailla omaa valuuttaa. Juuri tämä piirre on tehnyt eurosta erityisen tehokkaan välineen työvoiman alistamisessa, kuten esimerkiksi Kreikan kanssa vuonna 2015 käydyt "neuvottelut" ja niihin liittyvät EKP:n toimet osoittavat. Juuri siksi, että raha on irrotettu täydellisesti julkisista menoista ja keskuspankki poliittisesta kontrollista, voitiin pankkijärjestelmän tarvitseman keskuspankkirahan myöntämistä käyttää suorana poliittisena kiristyskeinona. Yllä mainittu esimerkki siitä, miten bulgarialaiset pankit saivat lainata keskuspankkirahaa suoraan EKP:sta, mutta kreikkalaiset pankit eivät, on tästä kaikkein suoraviivaisin osoitus.

\section{LOPUKSI: EI VAIN VALUUTTA}

Vaikka euro siis on epäilemättä toiminut eräänlaisena talouskuripolitiikan lukkona, tarkoitukseni on ollut osoittaa, että raha on ainoastaan yksi valtasuhde, joka on osa tiettyä finanssivetoisen kapitalismin "ordoliberaalin haaran" yleistä taloudellista hallintaa. Usein Maastrichtin sopimuksen parametrit fetisoidaan ja niitä jopa kutsutaan "kapitalismin rautaisiksi laeiksi", mutta kuten esimerkiksi Ranskan tapaus keväällä 2015 osoitti, säännöt eivät ole millään tavoin "rautaisia" vaan niiden soveltamisesta käydään jatkuvaa kamppailua. Ranska sai siis jopa luvan rikkoa alijäämäsäännöksiä - ja käytännössä voidaan olettaa, että se teki Saksan kanssa eräänlaisen sopimuksen, jossa Ranskan alijäämiä katsotaan läpi sormien, mikäli se asettuu Saksan puolelle Kreikan tai Syrizan vastaisessa rintamassa. Samoin Saksa on itse rikkonut alijäämäsäännöksiä 2000-luvun alkupuolella.

Niinpä iänikuisen euro vai oma valuutta -jankkauksen sijaan olisi astuttava syrjään tästä olemassa olevien poliittisten instituutioiden logiikan määrittämästä kysymyksenasettelusta ja katsottava: mitä ovat ne valtasuhteet, muutokset työvoiman kokoonpanossa, työn ja tuotannon sekä tulonjaon järjestämisen tavoissa, joihin euro rahana, maksujärjestelmänä ja komennon muotona liittyy. Miten näitä suhteita voitaisiin muuttaa, ja millainen merkitys itse rahajärjestelmää koskevilla kysymyksillä on tästä näkökulmasta? Jos kansalliseen valuuttaan paluun pääasiallisena etuna nähdään ulkoisen devalvaation mahdollisuus pelkän sisäisen devalvaation sijaan, yleensä taustalla on ainoastaan ajatus vientiteollisuusvetoisesta mallista ja vientiteollisuuden kilpailukyvyn parantamisesta. Myös vasemmistolaiset versiot omaan valuuttaan paluusta vaativat abstraktisti "työllistämistä" tai jopa uudelleenteollistamista kysymättä edes, minkälaista työttömänä tai tulottomana nykyisin oleva työvoima on luonteeltaan.

Olen tarkastellut euroa ja Saksan mallin levittämistä koko euroalueelle yhtenä yrityksenä ratkaista fordismin kriisiä, jonka taustalla olivat 1960- ja 1970 -lukujen kiihtyneet työläistaistelut sekä feministisen liikkeen taistelut, jotka kyseenalaistivat työvoimakustannusten ulkoistamisen naisten ilmaisen kotityön piiriin. Finanssikriisin käynnistymiseen asti euroalueen makrotaloudellinen järjestys perustui globaalille finanssikapitalismille ominaiseen kaksinapaiseen malliin, jossa tietyillä alueilla otettiin velkaa ja ostettiin sillä toisten, matalapalkkaisempien alueiden vientituotteita. Kotitalouksien kulutuskyky perustui ennen 
kaikkea velaksi ostetun asunnon (tai muun omaisuuden) arvonnousuun. Kaksinapaiseen malliin liittyi (ja osin liittyy edelleen) myös eräänlainen työvoiman uusintamisjärjestyksen kaksijakoisuus: velkaantuneilla alueilla hoivan siirtäminen markkinoiden (usein siirtolaisnaisten matalapalkkaisen työn) piiriin ja vientiteollisuusalueilla edelleen familialistisen mallin mukaisesti kotitalouden piiriin (eli naisten harteille). Finanssikriisin myötä talouskuria ja matalapalkkamallia on yritetty levittää koko euroalueelle, ja sen vanavedessä seuraa familialistinen hoivapolitiikka, joka näkyy esimerkiksi Sipilän hallituksen päivähoitoleikkauksissa.

Kokonaisvaltaisesti EKP ja euroryhmä näyttävät tällä hetkellä pyrkivät vanhaan, kaikkien muiden paitsi finanssialan kannalta huonoksi havaittuun keinoon: palkat ja investoinnit alas, varallisuuserien arvot ylös. EKP yrittää määrällisen kevennyksen keinoin kasvattaa kulutuskysyntää paisuttamalla matalien korkojen avulla tiettyjen omaisuuserien, ennen kaikkea asuntojen arvoja, mutta ei näytä onnistuvan tässä tavoitteessa. Tietyissä maissa, kuten Hollannissa, Saksassa ja Suomessa märällinen kevennys on edesauttanut asuntohintojen nousun jatkumista, mutta vaikutukset kysyntään ovat vähäisiä, koska esimerkiksi Saksassa edelleen vain hyvin pieni osa kotitalouksista omistaa itse asuntonsa ja todennäköisesti kiinteistöjen hinnannousu tulee hyödyttämään pikemminkin institutionaalisia sijoittajia.

Esimerkiksi Financial Timesin päätalouskolumnisti Martin Wolf (2016) sekä lukuisat taloustieteilijät ovatkin ehdottaneet, että EKP:n tulisi velkakirjaostojen sijaan tai ohella luoda rahaa suoraan euroalueen kansalaisille, koska se näyttää tällä hetkellä ainoalta keinol-

\section{VIITTEET}

1. https://www.ecb.europa.eu/press/pr/stats/bop/2015/ html/bq151008.en.html

2. Yleisesti ottaen niin jälkikeynesiläisen kuin marxilaisen teorian näkökulmasta inflaatio ei liity rahan määrään vaan on viime kädessä ilmaus työvoiman ja pääoman ta kasvattaa efektiivistä kysyntää. Sen lisäksi, että nykyisen kaltainen määrälinen kevennys ei näytä edes merkittävästi lisäävän yritysten luototusta, yritykset eivät myöskään halua työllistää, koska tuotannon kasvattamiselle ei löydy perusteita heikossa kysyntätilanteessa. Rahan antaminen työvoimalle ilman yritysten välitystä olisi siis olennaista kulutuskysynnän kannalta, mutta samalla se toimisi keinona ratkaista double bind, johon euroalueen työvoima näyttää olevan sidottu. Tällainen erityisistä työsuorituksista irrotettu rahatulon muoto tulisi nähdä investointina loogiselta tyypiltään korkeampaan kommunikaatioon ja kanssakäymiseen, "oppimaan oppimiseen", yleisten kykyjen eikä pelkästään erityisten kykyjen omaksumiseen.

Kasvattaessaan työvoiman neuvotteluasemaa perustulo tai "rahahuolien elvytys kansalaisille" toimisi keinona sitoa rahavirrat takaisin kysyntää luoviin investointeihin vastaavalla tavoin kuin palkankorotukset fordismin aikana. Koska raha yleisenä ostovoimana eroaa erilaisista maksusitoumuksista nimenomaan siksi, että rahaa voidaan käyttää maksuvälineenä ja varallisuuden siirtämisen välineenä yhtäläisesti koko voimassaoloalueellaan, Euroopan laajuinen perustulo voisi toimia keinona tehdä eurosta euroalueen yhteinen, reaalista ostovoimaa yhtäläisesti koko euroalueella merkitsevä valuutta, sillä se lisäisi alueen asukkaiden kykyä liikkua alueen sisällä. Samalla sen ympärille tulisi tietenkin rakentaa kamppailu EKP:n mandaatin muuttamiseksi, sillä tavoin että sen tehtävänä ei enää olisi pelkästään vientiteollisuuden tai finanssimarkkinoiden tukeminen vaan työvoiman itsenäisyyden ja sen kautta makrotaloudellisen vakauden kasvattaminen.

välisestä valtasuhteesta (Rowthorn 1977). Viime vuosikymmenten kehitys, jonka seurauksena finanssikriisiin asti laveassa raha-aggregaatissa kiertäneen rahan määrä nousi räjähdysmäisesti mutta inflaatio pysyi äärimmäisen matalana, osoittaa melko suoraan vääräksi monetaristisen käsityksen inflaatiosta ja tukee ajatusta siitä, 
että inflaation mataluus liittyy nimenomaan palkkakehityksen ja työväenliikkeen heikkouteen (ks. Marazzi 1994).

3. https://research.stlouisfed.org/fred2/series/CSHC-

\section{KIRJALLISUUS}

Aglietta, Michel (1997): Régulation et crises du capitalisme. Odile Jacob, Paris.

Aglietta, Michel (2012): Zone euro - éclatement ou fédération, Michalon, Paris.

Aglietta, Michel \& Brand, Thomas (2014): Un New Deal para Europa. Crecimiento, euro, competividad, käänt. Ana Useros Martín, Traficantes de Sueños, Madrid.

Aglietta, Michel \& Jean Cartelier (1998): "Ordre monétaire des économies de marché", teoksessa Michel Aglietta \& André Orlean (toim.): La monnaie souveraine, Odile Jacob, Paris,129-158.

Aglietta, Michel, Jean Andreau \& Mark Anspach (1998): "Introduction", teoksessa Aglietta \& Orlean 1998, 9-34..

Boyer, Robert (2004): The Future of Economic Growth. As New Becomes Old, Edward Elgar, London.

Brenke, Karl (2009): "Real Wages in Germany: Numerous Years of Decline", DIW Weekly Report, 5/2009, 193-202.

Brenner, Robert (2002): The Boom and the Bubble. The US in the World Economy, Verso, London.

Brenner, Robert (2006): The Economics of Global Turbulence: the Advanced Capitalist Economies from Long Boom to Long Downturn, Verso, London.

Connolly, Bernard (1997): The Rotten Heart of Europe. The Dirty War for Europe's Money, Faber\&Faber, London.

Coppola, Frances (2015): "The Road to Grexit", Forbes 3.7.2015.

Destatis (2012): "Licht und Schatten am Arbeitsmarkt", Destatis (Statistisches Bundesamt), 11.1.2012.

De Grauwe, Paul \& Yuemei Ji (2013): "Panic-driven austerity in the Eurozone and its Implications", Voxeu.org (CEPR's Policy Portal) 21.2.2013.

Esping-Andersen, Gösta (1990): The Three Worlds of Welfare Capitalism, Princeton University Press.

Euroopan keskuspankki (2015): "Real convergence in the euro area: evidence, theory and policy implications", ECB Economic Bulletin 5/2015, https://www.ecb.euro-
CPDEA156NRUG lähde University of Groningen, University of California, Davis.

4. http://data.worldbank.org/indicator/SL.TLF.CACT. ZS.

pa.eu/pub/pdf/other/eb201505_article01.en.pdf Euroopan komissio (2013): Competing in Global Value Chains. EU Industrial Structure Report 2013, Publications Office of the European Union, Luxembourg.

Foucault, Michel (2014): Naissance de la biopolitique. Cours au Collège de France 1978-79, Gallimard/Seuil, Paris.

Fox Piven, Frances \& Cloward, Richard (1971): Regulating the Poor. The Functions of Public Welfare, Pantheon Books, New York.

Fratzscher, Marcel (2004): Die Deutschland-Illusion, Carl Hanser Verlag, Hamburg.

Gambino, Ferruccio (1997): "Critica del fordismo della scuola regolazionista", teoksessa Eugenia Parise (toim.): Stato nazionale, lavoro e moneta, Liguori, $\mathrm{Na}-$ poli.

Graziani, Augusto (2003): A monetary theory of production, Cambridge UP.

Grippner, Kreta (2011): Capitalizing on Crisis. The Political Origins of the Rise of Finance, Harvard University Press, Cambridge (Mass.).

Lopez,Isidro \& Rodriguez, Emmanuel (2010): Fin de ciclo. Financiarizacion, territorio y sociedad de propiotarios en la onda larga del capitalismo hispano (1959-2010), Traficantes de Suenos, Madrid.

Marazzi, Christian (1998): E il denaro va, Bollati Boringhieri, Torino.

Marazzi, Christian (1994): Il posto dei calzini, Bollati Boringhieri, Torino.

Marazzi, Christian (2015): Finanssikapitalismin väkivalta, Tutkijaliitto, Helsinki.

Marsh, David (1992): The Bundesbank. The Bank that Rules Europe, Heinemann, London.

Marsh, David (2009): The Euro, Yale University Press, New Haven and London.

Marsh, David (2013): Europe's Deadlock, Yale University Press, New Haven and London.

Mazzucato, Mariana (2013): The Entrepreneurial State, Anthem Press, London.

Minijob-Zentrale (2015): "Aktuelle Entwicklungen im Bereich der geringfügigen Beschäftigung", Deutsche 
Rentenversicherung Knappschaft-Bahn-See / Minijob-Zentrale, Essen, https://www.minijob-zentrale. de/DE/Service/03_service_rechte_navigation/ DownloadCenter/6_Berichte_und_Statistiken/1_ Quartalsberichte_d_MJZ/2015/quartal_4_2015. pdf?_blob=publicationFile $\& v=2$

Moravcsik, Andrew (1998): The Choice for Europe. Social Purpose and State Power from Messina to Maastricht, Cornell UP, Ithaca (NY.).

O'Connor, James (1973): Fiscal Crisis of the State, St. Martin's Press, New York.

Panitch, Leo \& Gindin, Sam (2012): The Making of Global Capitalism: the Political Economy of American Empire, Verso, London.

Pettis, Michael (2013): The Great Rebalancing. Trade, Conflict and the Perilous Road Abead for the World Economy, Princeton University Press, Princeton and Oxford.
Rossi, Sergio (2013): "Financialization and monetary union in Europe: the monetary-structural causes of the euro-area crisis", Cambridge Journal of Regions, Economy and Society (2013) 6 (3), 351-357.

Rowthorn, Robert (1977): "Conflict, Inflation and Money", Cambridge Journal of Economics 1977:1, 215-239. Sapir, Jacques (2012): Faut-il sortir de l'euro, Seuil, Paris.

Schmitt, Bernard (1966): Monnaie, salaires et profits, PUF, Paris.

Streeck, Wolfgang (2015): Ostettua aikaa. Demokraattisen kapitalismin lykätty kriisi, Vastapaino, Tampere.

Varoufakis, Yanis (2014): Maailmantalouden minotauros, Vastapaino, Tampere.

Wolf, Martin (2014): The Shifts and the Shocks, Penguin Press, London ja New York.

Wolf, Martin (2016): "Prepare for the next recession", Financial Times 5.2.2016 